\title{
Neuron-Specific Inactivation of the Hypoxia Inducible Factor $1 \alpha$ Increases Brain Injury in a Mouse Model of Transient Focal Cerebral Ischemia
}

\author{
Oxana Baranova, ${ }^{1}$ Luis F. Miranda, ${ }^{1}$ Paola Pichiule, ${ }^{3}$ Ioannis Dragatsis, ${ }^{4}$ Randall S. Johnson, ${ }^{5}$ and Juan C. Chavez ${ }^{1,2}$ \\ ${ }^{1}$ Burke Medical Research Institute, White Plains, New York 10605, ${ }^{2}$ Department of Neurology and Neuroscience, Weill Cornell Medical College, New York, \\ New York 10021, 3 ${ }^{3}$ epartment of Pediatrics, Morgan Stanley Children's Hospital, Columbia University, New York, New York 10032, ${ }^{4}$ Department of \\ Physiology, The University of Tennessee, Health Science Center, Memphis, Tennessee 38163, and ${ }^{5}$ Molecular Biology Section, Division of Biology, \\ University of California, San Diego, La Jolla, California 92093
}

In the present study, we show a biphasic activation of hypoxia inducible factor $1 \alpha$ (HIF-1) after stroke that lasts for up to $10 \mathrm{~d}$, suggesting the involvement of the HIF pathway in several aspects of the pathophysiology of cerebral ischemia. We provide evidence that HIF-1mediated responses have an overall beneficial role in the ischemic brain as indicated by increased tissue damage and reduced survival rate of mice with neuron-specific knockdown of HIF-1 $\alpha$ that were subjected to transient focal cerebral ischemia. In addition, we demonstrated that drugs known to activate HIF-1 in cultured cells as well as in vivo had neuroprotective properties in this model of cerebral ischemia. This protective effect was significantly attenuated but not completely abolished in neuron-specific HIF-1 $\alpha$-deficient mice, suggesting that alternative mechanisms of neuroprotection are also implicated. Last, our study showed that hypoxia-induced tolerance to ischemia was preserved in neuron-specific HIF- $1 \alpha$-deficient mice, indicating that the neuroprotective effects of hypoxic preconditioning do not depend on neuronal HIF-1 activation.

Key words: stroke; hypoxia; preconditioning; gene expression; neuroprotection; HIF

\section{Introduction}

Numerous experimental and clinical studies have shown that ischemic brain injury after stroke is a dynamic process that evolves over a period of hours to several days, particularly in the area surrounding the core of the infarct known as the penumbra (Dirnagl et al., 1999; Sharp et al., 2000). This process includes several events such as oxidative stress, cell death, inflammation, as well as activation of endogenous adaptive and regenerative mechanisms. Regulation of many of these processes occurs at the transcriptional level and involves the concerted activation of various transcription factors, including the hypoxia inducible factor (HIF).

HIF is a heterodimer of HIF- $\alpha$ and HIF- $\beta$ subunits: three distinct and nonredundant HIF- $\alpha$ subunits [HIF- $1 \alpha$, HIF- $2 \alpha$ / EPAS1 (endothelial PAS domain protein 1), and HIF-3 $\alpha$ ], as well as three HIF- $\beta$ subunits [HIF-1 $\beta$ /ARNT1 (aryl hydrocarbon re-

\footnotetext{
Received Jan. 31, 2007; revised April 16, 2007; accepted April 17, 2007.

This work was supported in part by the W. M. Burke Foundation. J.C.C. is the recipient of a Transition to Independence Award from the Horace W. Goldsmith Foundation and Scientist Developing Grant 0635556T from the Northeast Affiliate of the American Heart Association. P.P. is the recipient of Postdoctoral Fellowship 0525870T from the Heritage Affiliate of the American Heart Association. We thank Dr. Rajiv Ratan for his generous support of this project. We also thank Jin Son, Harriet Baker, Bruce Kristal, Bruce Volpe, Philipp Lange, and Gary Gibson for sharing various materials and for their invaluable advice and encouragement throughout this study. This work was possible because of the outstanding technical support from Hsin-Hwa Lee, Chu-Hui Peng, and Lucretia Batten.

Correspondence should be addressed to Dr. Juan C. Chavez, Burke Medical Research Institute, 785 Mamaroneck Avenue, White Plains, NY 10605. E-mail: jcc2005@med.cornell.edu, jchavez@burke.org.

D0I:10.1523/JNEUROSCI.0449-07.2007

Copyright $\odot 2007$ Society for Neuroscience $\quad$ 0270-6474/07/276320-13\$15.00/0
}

ceptor nuclear translocator 1), ARNT2, and ARNT3] are currently known (Bruick and McKnight, 2002). The expression of the HIF- $\alpha$ subunits is regulated by oxygen levels, whereas the expression of the HIF- $\beta$ subunits is constitutive (Wang and Semenza, 1993, 1995; Wang et al., 1995; Semenza et al., 1997; Bruick, 2003). During normoxia, the HIF- $\alpha$ protein is expressed, but it is rapidly hydroxylated at two conserved proline residues; this oxygen-dependent posttranslational modification is catalyzed by the EGLN [egl nine homolog 1 (C. elegans)] family of HIF prolyl hydroxylases (Bruick and McKnight, 2001; Ivan et al., 2001; Jaakkola et al., 2001). The hydroxylated prolines are recognized by the product of the Von-Hippel Lindau tumor suppressor gene that targets HIF- $\alpha$ protein for ubiquitination and subsequent proteosomal degradation, such that almost no HIF- $\alpha$ protein accumulates (Salceda and Caro, 1997; Huang et al., 1998). Under hypoxic conditions, nonhydroxylated HIF- $1 \alpha$ protein escapes proteosomal degradation, accumulates within the nucleus, and dimerizes with the HIF- $\beta$ subunit forming the active HIF complex. The most widely expressed and best characterized $\alpha$ subunit in the hypoxic/ischemic brain is HIF- $1 \alpha$, and its expression has been described in both neurons and glia (Bergeron et al., 1999; Chavez et al., 2000; Chavez and LaManna, 2002). In addition, HIF- $2 \alpha$ is also induced in the hypoxic brain, and its expression was found in astrocytes and endothelial cells (Chavez et al., 2006). Importantly, HIF-1 and HIF-2 appear to regulate a distinct subset of target genes (Wiesener et al., 2003; Warnecke et al., 2004). 
Despite the undisputed role of HIF-1 in regulating oxygen homeostasis, its role in the pathophysiology of stroke is still not well established. Several studies using various models of focal and global cerebral ischemia have shown that HIF- $1 \alpha$ protein accumulation correlates with the expression of target genes that encode proteins involved in various adaptive responses (Semenza, 2000; Sharp et al., 2001; Chavez and LaManna, 2002; Bernaudin et al., 2002b; Sharp and Bernaudin, 2004). These include glycolytic enzymes and glucose transporters, angiogenic modulators, and trophic factors, among others. In addition, several studies have documented that HIF-1 participates in hypoxia-induced cell death events by activating the expression of various pro-death genes, such as the $\mathrm{Bcl}$ homology 3-only protein bNIP3 ( $\mathrm{Bcl} 2 /$ adenovirus E1B $19 \mathrm{kDa}$ interacting protein 3) (Bruick, 2000; Althaus et al., 2006). Whether the HIF-mediated deleterious effects predominate over the prosurvival responses or vice versa in the context of focal ischemia remains unknown.

To study the role of HIF- $1 \alpha$ in the progression of ischemic brain injury, we took advantage of the Cre/Lox technology to generate conditional mutant mice with deletion of HIF- $1 \alpha$ predominantly in neurons of the forebrain. These mutant mice were subjected to transient focal cerebral ischemia induced by middle cerebral artery occlusion (MCAo) and allowed to recover for various time points. We also evaluated the effectiveness of known pharmacologic HIF activators to define whether HIF-1 is a relevant target for therapeutic intervention after stroke. In addition, we explored the role of neuronal HIF-1 in mediating the neuroprotective effects of hypoxic preconditioning. Our study revealed that neuron-specific knockdown of HIF- $1 \alpha$ aggravated brain damage after MCAo. Conversely, augmenting the activity of HIF-1 using pharmacologic activators significantly reduced ischemic injury in wild-type mice, whereas the effectiveness of these compounds was significantly attenuated in mice with neuronspecific HIF- $1 \alpha$ knockdown. In addition, our study suggests that neuronal HIF-1 does not contribute to the protective effects of hypoxic preconditioning as indicated by the preservation of hypoxia-induced ischemic tolerance in neuron-specific HIF- $1 \alpha$ deficient mice.

\section{Materials and Methods}

Animals. All animal procedures were performed according to protocols approved by Institutional Animal Care and Use Committee of The Weill Medical College of Cornell University. Mice carrying conditional HIF- $1 \alpha$ floxed alleles (HIF- $1 \alpha^{\mathrm{F}}$ ) were generated by engineering loxP sites flanking exon 2 of the HIF- $1 \alpha$ gene as described previously (Ryan et al., 2000). R1ag\#5 (R1) and L7ag\#13 (L7) mice expressing Cre recombinase under the control of the calcium/calmodulin-dependent kinase CaMKII promoter (CAMKII-Cre) were generated as described previously (Dragatsis and Zeitlin, 2000). Reporter transgenic mice ROSA26Sor-LacZ (Soriano, 1999) were purchased from The Jackson Laboratory (Bar Harbor, ME). All mouse strains were maintained on a C57BL/6J background. Rlag\#5 and L7ag\#13 mice were crossed with homozygote floxed HIF-1 $\alpha$ mice (HIF- $\left.1 \alpha^{\mathrm{F} / \mathrm{F}}\right)$ to generate $\mathrm{Cre}(+): \mathrm{HIF}-1 \alpha^{\mathrm{F} / \mathrm{Wt}}$. These mice were crossed with homozygote HIF- $1 \alpha^{\mathrm{F} / \mathrm{F}}$ mice to generate conditional HIF- $1 \alpha$ mutants Cre $(+):$ HIF- $1 \alpha^{\mathrm{F} / \mathrm{F}}$ designated HIF- $1 \alpha^{\Delta / \Delta}$. Littermates with the $\mathrm{Cre}(-): \mathrm{HIF}-1 \alpha^{\mathrm{F} / \mathrm{F}}$ genotypes and wild-type C57BL6/J mice $(\mathrm{Wt})$ were used as controls for each experiment.

Genotyping. Genomic DNA was isolated from tail biopsies collected at $21 \mathrm{~d}$ of age using the DNeasy genomic DNA isolation kit (Qiagen, Valencia, CA) following the procedure described by the manufacturer. Genotyping was performed using PCR. HIF- $1 \alpha^{\mathrm{F}}$ and wild-type alleles were detected using the following primers: 5'-GCAGTTAAGAGCACTAGTTG- $3^{\prime}$ and $5^{\prime}$-GGAGCTATCTCTCTAGACC- ${ }^{\prime}$ ' Transgenic mice expressing Cre recombinase were identified using primers that detect the Cre gene: 5'-CCGGGCTGCCACGACCAA-3' and 5'-
GGCGCGGCAACACCATTTTT-3'. The products were run on a $5 \%$ acrylamide gel (for HIF- $1 \alpha$ ) or a $1 \%$ agarose gel (for Cre).

Analysis of Cre mediated HIF-1 $\alpha$ exon 2 excision in the brain. To determine the extent of HIF- $1 \alpha$ deletion in HIF- $1 \alpha^{\Delta / \Delta}$ mice, a standard Southern blot analysis was performed as described previously (Ryan et al., 2000). For this purpose, genomic DNA was isolated from cerebellum, cortex, and striatum of Cre $(+)$ :HIF- $1 \alpha^{\mathrm{F} / \mathrm{F}}$ [embryonic day 16 (E16) to postnatal day 90 (P90)]. Southern blots were performed using $15 \mu \mathrm{g}$ of genomic DNA that was digested with EcoRI and PstI. After blotting, the nylon membranes were hybridized with a ${ }^{32} \mathrm{P}$-labeled 700 bp probe obtained from an EcoRI/BglII digestion of pBSKHif $1 \alpha$. The hybridization signal was visualized and quantified in a PhosphorImager (Fujifilm, Elmsford, NY). The undeleted allele (HIF- $1 \alpha^{\mathrm{F}}$ ) was represented by a 2.2 $\mathrm{kb}$ fragment, and the deleted allele (HIF- $1 \alpha^{\Delta}$ ) was represented by a $1.3 \mathrm{~kb}$ fragment.

Systemic hypoxia. Wild-type 2-month-old male C57BL/6J mice (The Jackson Laboratory) and HIF- $1 \alpha^{\Delta / \Delta}$ mice were exposed to hypoxia ( $8 \%$ $\mathrm{O}_{2}$ ) for $12 \mathrm{~h}$ in a Plexiglas chamber as described previously (Chavez et al., 2000; Chavez and LaManna, 2002). Immediately after hypoxia, animals were killed with $\mathrm{CO}_{2}$ and decapitated, and the cerebral cortical mantle was dissected and frozen for subsequent analysis.

Cerebral ischemia. Transient focal cerebral ischemia was induced by MCAo using the intraluminal filament method (Nogawa et al., 1997). Male mice $(20-25 \mathrm{~g})$ were anesthetized with $1.5 \%$ isoflurane in a mixture of $70 \%$ nitrogen $/ 30 \%$ oxygen. A small incision was performed in the skin covering the scalp, and a fiber optic probe was glued to the parietal bone ( $2 \mathrm{~mm}$ posterior and $5 \mathrm{~mm}$ lateral to bregma) and connected to a laser Doppler flow meter (Periflux System 5010; Perimed, Järfälla, Sweden) for continuous monitoring of cerebral blood flow (CBF) in the center of the ischemic territory. The left common carotid artery bifurcation was exposed through a midline neck incision; a heat-blunted black monofilament surgical suture (6-0) was inserted into the exposed external carotid artery, advanced into the internal carotid artery, and wedged into the circle of Willis to obstruct the origin of the MCA. The filament was left in place for $30 \mathrm{~min}$ and then withdrawn. Only animals that exhibited $>85 \%$ reduction in CBF during MCAo and at least $80 \%$ of CBF restoration within $10 \mathrm{~min}$ of reperfusion were included in the study. During the surgical procedure, systemic temperature was monitored with a rectal probe and maintained at $37.0 \pm 0.5^{\circ} \mathrm{C}$ until animals regained consciousness. This stroke model leads to reproducible infarcts involving both the cerebral cortex and the striatum with sparing of the hippocampus proper. Sham-operated animals were subjected to similar surgical procedures without occlusion of the MCA. At the indicated time points, mice were killed, and their brains were removed and frozen in dry-ice chilled isopentane for histological analysis. For immunoblot and quantitative PCR analysis, ipsilateral and contralateral hemispheres were separated before freezing.

Physiologic parameters. Because arterial catheterization is not compatible with long-term survival in mice, animal physiology was assessed in a separate set of each transgenic strain $(n=5)$. For this purpose, the left femoral artery was cannulated using a polyethylene tube (PE-10) to record mean arterial blood pressure. In addition, blood samples $(200 \mu \mathrm{l})$ were collected to measure blood gases, total glucose, and lactate levels 15 min before ischemia and $15 \mathrm{~min}$ after the onset of reperfusion. These mice were killed $1 \mathrm{~h}$ after reperfusion.

Quantification of infarct volume. Coronal brain sections were cut serially ( $25 \mu \mathrm{m}$ thickness at $250 \mu \mathrm{m}$ intervals) in a cryostat (Leica, Nussloch, Germany) and stained with cresyl violet to identify viable tissue. Image acquisition and analysis was performed using an Axiovert 200M (Zeiss, Oberkochen, Germany) inverted microscope driven by the image analysis software NeuroLucida (MicroBrightField, Williston, VT). To correct for the effect of edema, the infarcted area was determined indirectly by subtracting the area of the healthy tissue in the ipsilateral hemisphere from the area of the contralateral hemisphere on each section. Infarction volume was calculated by integration of infarct areas measured in 12 equidistant brain sections that encompassed the whole lesion.

Neurological evaluation. Neurological deficits were assessed by a scoring system using a modification of the postural reflex test (Bederson et al., 1986). The examiner was kept blind to treatment and identity of the 
animals. Neurological scores were assigned the following values: 0 , normal motor function; 1 , flexion of torso and contralateral forelimb when mouse was lifted by the tail; 2 , circling to the contralateral side when mouse was held by the tail on a flat surface but normal posture at rest; 3 , leaning to the contralateral side at rest; 4 , no spontaneous motor activity. Mice were evaluated before MCAo to establish a baseline and at various time points during recovery.

Preparation of whole-cell lysates. Tissue samples were homogenized with a Dounce glass homogenizer using ice-cold lysis radioimmunoprecipitation assay buffer $(1 \times$ PBS, $1 \%$ Nonidet P-40, $0.5 \%$ sodium deoxycholate, and $0.1 \%$ SDS) supplemented with protease inhibitors (Complete; Roche, Indianapolis, IN). Lysates were centrifuged at 10,000 $\times g$ for $10 \mathrm{~min}$ at $4^{\circ} \mathrm{C}$, and supernatants were collected. In all cases, protein concentrations were determined by a Bradford protein assay with bovine serum albumin used as standards (Bio-Rad, Hercules, CA).

Quantitative Western blot analysis. Cell lysates ( $25 \mu \mathrm{g}$ of protein) were electrophoresed on SDS-PAGE under reducing conditions and transferred to a nitrocellulose membrane (Bio-Rad) by standard procedures. Membranes were blocked with a 1:1 dilution of LI-COR blocking solution (LI-COR Biosciences, Lincoln, NE) in TBS containing 0.05\% Tween 20 (Bio-Rad). After blocking, membranes were incubated with the same blocking solution containing the following primary antibodies: mouse monoclonal antibodies against HIF- $1 \alpha$, HIF- $1 \beta$, and HIF- $2 \alpha$ and rabbit polyclonal antibodies against Nix (NIP3-like protein X)/bNIP3L and Noxa (NADPH oxidase activator 1 ) were purchased from Novus Biologicals (Littleton, $\mathrm{CO}$ ); rabbit polyclonal antibodies against erythropoietin (Epo), vascular endothelial growth factor A (VEGF), $\alpha$-tubulin, $\beta$-actin, bNIP3, and RTP801-REDD-1 were purchased from Santa Cruz Biotechnology (Santa Cruz, CA). After washing, membranes were incubated at room temperature for $2 \mathrm{~h}$ in the same buffer with the appropriate IRDye680 and IRDye800 secondary antibodies (1:10,000; LI-COR Biosciences) and then washed again in TBS/0.05\% Tween 20 . A final wash was done in TBS, and the blot was visualized using an Odyssey infraredimaging system (LI-COR Biosciences). Samples were corrected for background and quantified using Odyssey software. All values were normalized to a housekeeping protein and expressed as fold increase relative to control.

Real-time PCR analysis. After indicated time points, brains were harvested and total RNA was extracted using an RNA extraction kit (RNAgents; Promega, Madison, WI). Complementary DNA was synthesized from $2.5 \mu \mathrm{g}$ of total RNA using the Superscript III system with oligo-dT (18) primer (Invitrogen, Carlsbad, CA). Real-time PCR analysis was performed with $0.5 \mu \mathrm{l}$ of the final cDNA synthesis mix using mousespecific Taq-Man-based gene expression assays (Applied Biosystems, Foster City, CA). The following assays were used: Vegf (Mm00437304_m1), Epo (Mm00433126_m1), lactate dehydrogenase (Mm00495282_g1), glucose transporter 1 (Glut-1) (Mm00441473_m1), $\beta$-actin (Mn00607939_s1), Pmaip1 (phorbol-12-myristate-13-acetate-induced protein 1)/Noxa (Mm00451763_m1), bNIP3 (Mm00833810_g1), Nix (Mm00786306_s1), RTP801/REDD-1/dexamethasone induced gene 2 (Mm00512503_g1), angiopoietin 2 (Ang-2) (Mm00545822_m1), Flk-1 (flagellar assembly regulatory protein 1 )/Kdr (kinase insert domain protein receptor)/VEGF receptor-2 (Mm01222419_m1), Flt-1/VEGF receptor-1 (Mm00438980_m1), and PAI-1 (plasminogen activator inhibitor-1) (Mm00435860_m1). The PCR reaction was performed in an ABI 7500 real time PCR thermocycler (Applied Biosystems). All reactions were performed in duplicate using $\beta$-actin as an endogenous control.

Cerebral macrovascular morphology. To assess the morphology of major cerebral blood vessels of the circle of Willis, animals were deeply anesthetized with isofluorane, and a P10 catheter was implanted in the external jugular vein to administer heparin $(200 \mathrm{U})$ and a lethal dose (50 $\mathrm{mg} / \mathrm{kg}$ ) of papaverin (Sigma, St. Louis, MO) in normal saline. Immediately after infusion of the vasodilator papaverin, mice were perfused transcardially with a prewarmed $\left(37^{\circ} \mathrm{C}\right)$ saline solution containing gelatin $(20 \% \mathrm{w} / \mathrm{v})$ and India Ink $(0.25 \% \mathrm{v} / \mathrm{v})$. Brains were carefully removed using a dissecting microscope and postfixed in $4 \%$ paraformaldehyde.

Cerebral microvascular density. HIF- $1 \alpha^{\mathrm{F} / \mathrm{F}}, \mathrm{R} 1-\mathrm{HIF}-1 \alpha^{\Delta / \Delta}$, and L7HIF-1 $\alpha^{\Delta / \Delta}$ male mice of 3 months of age were killed and perfused/fixed with PBS and $4 \%$ paraformaldehyde. Brains were removed, cryopre- served in $30 \%$ sucrose, and sectioned in a cryostat (Leica). Microvascular density was assessed in the parietal cortex as described previously ( $\mathrm{Pi}$ chiule and LaManna, 2002). Immunofluorescent staining for the endothelial-specific marker CD31/platelet-endothelial cell adhesion molecule was performed in five sets of three sections ( $8 \mu \mathrm{m}$ thick) cut 150 $\mu \mathrm{m}$ apart corresponding approximately to plates $12-16$ in a mouse brain atlas (Franklin and Paxinos, 2000). The staining was visualized by incubating the sections with a second antibody conjugated with AlexaFluor 452 (Invitrogen). Composite images spanning the full depth of the parietal cortex and the entire area of the striatum were obtained using an Axiovert 200M inverted microscope equipped with an AxioCam-XMR camera (Zeiss). Images were analyzed using the AxioVision software to determine the number of CD31-positive capillary profiles per unit area that were $<20 \mu \mathrm{m}$ in diameter. Cortical and striatal capillary densities were expressed as the mean \pm SD of 15 composite images obtained from each brain.

Immunohistochemistry. Coronal sections $(25 \mu \mathrm{m})$ were cut in a Leica cryostat and mounted on Superfrost slides (VWR International, West Chester, PA). Sections were fixed with ice-cold methanol $\left(-20^{\circ} \mathrm{C}\right)$ and incubated with PBS containing $0.4 \%(\mathrm{v} / \mathrm{v})$ Triton X-100 and $1 \%(\mathrm{w} / \mathrm{v})$ ELISA grade bovine serum albumin for $1 \mathrm{~h}$. Subsequently, sections were incubated overnight at $4^{\circ} \mathrm{C}$ with a rabbit polyclonal antibody against HIF-1 $\alpha$ (1:200; AB1536; R \& D Systems, Minneapolis, MN). HIF- $1 \alpha-$ positive cells were visualized with a secondary anti-rabbit antibody and conjugated with AlexaFluor 488 (Invitrogen).

Sections from the ROSA26Sor-LacZ reporter mouse were stained for $\beta$-galactosidase using a polyclonal rabbit anti- $\beta$-galactosidase antibody (1:500; ICN Biomedicals, Orsay, France) that was detected using an antirabbit antibody conjugated with AlexaFluor 564 (1:100; Invitrogen). Double staining for a neuronal-specific marker was performed using the Mouse on Mouse System (Vector Laboratories, Burlingame, CA) and a mouse monoclonal antibody against neuronal-specific nuclear protein (NeuN) (Chemicon, Temecula, CA). The signal was visualized using streptavidin conjugated with cyanine 3 (Jackson ImmunoResearch, West Grove, PA). The immunofluorescent staining was analyzed and documented using a Nikon (Tokyo, Japan) Eclipse 80i microscope equipped with a DXR1200C color digital camera.

Drug delivery. Desferrioxamine mesylate (Sigma) was dissolved in PBS and administered subcutaneously at a dose of $300 \mathrm{mg} / \mathrm{kg}$ of body weight. 2,2'-Dipyridyl (DP) (Sigma) was dissolved in absolute ethanol (0.4 $\mathrm{g} / \mathrm{ml}$ ), and the alcoholic solution was diluted 1:200 in $0.9 \% \mathrm{NaCl}$ and administered intraperitoneally at a dose of $20 \mathrm{mg} / \mathrm{kg}$. Ethyl 3,4dihydroxy benzoate (DHB) (Sigma) was dissolved in ethanol and administered intraperitoneally at a dose of $200 \mathrm{mg} / \mathrm{kg}$ of body weight. All of the drugs were administered $6 \mathrm{~h}$ before MCAo (pretreatment) and $6 \mathrm{~h}$ after MCAo (posttreatment). The effects of drug treatments were measured $4 \mathrm{~d}$ after the onset of ischemia and compared with those of corresponding vehicles.

Statistical analysis. Data are presented as mean \pm SD. Statistical comparisons among groups were made using a one-way ANOVA test with Tukey's correction (SPSS 11.5; SPSS, Chicago, IL). A $p<0.05$ was considered statistically significant. The probability of survival after MCAo was calculated using the nonparametric Kaplan-Meier method.

\section{Results}

Stimulation of HIF- $1 \alpha$ accumulation after cerebral ischemia

The procedure used to occlude the MCA leads to reproducible infarcts involving both the cerebral cortex and the striatum with sparing of the hippocampus. Immunohistochemistry at $6 \mathrm{~h}$ of recovery indicated that HIF- $1 \alpha$ accumulation primarily occurred in NeuN-positive neurons located in the infarct core as well as in the surrounding areas (Fig. 1A). Few non-neuronal cells, like endothelial cells, were also expressing HIF-1 $\alpha$ at this time (data not shown). Quantitative Western blot analysis showed that cerebral ischemia induced by transient MCAo triggered a biphasic increase of HIF- $1 \alpha$ protein levels in the ischemic hemisphere, a response absent in the non-ischemic hemisphere (Fig. $1 B$ ). As early as $1 \mathrm{~h}$ after MCAo, there was a fourfold increase in HIF- $1 \alpha$ 

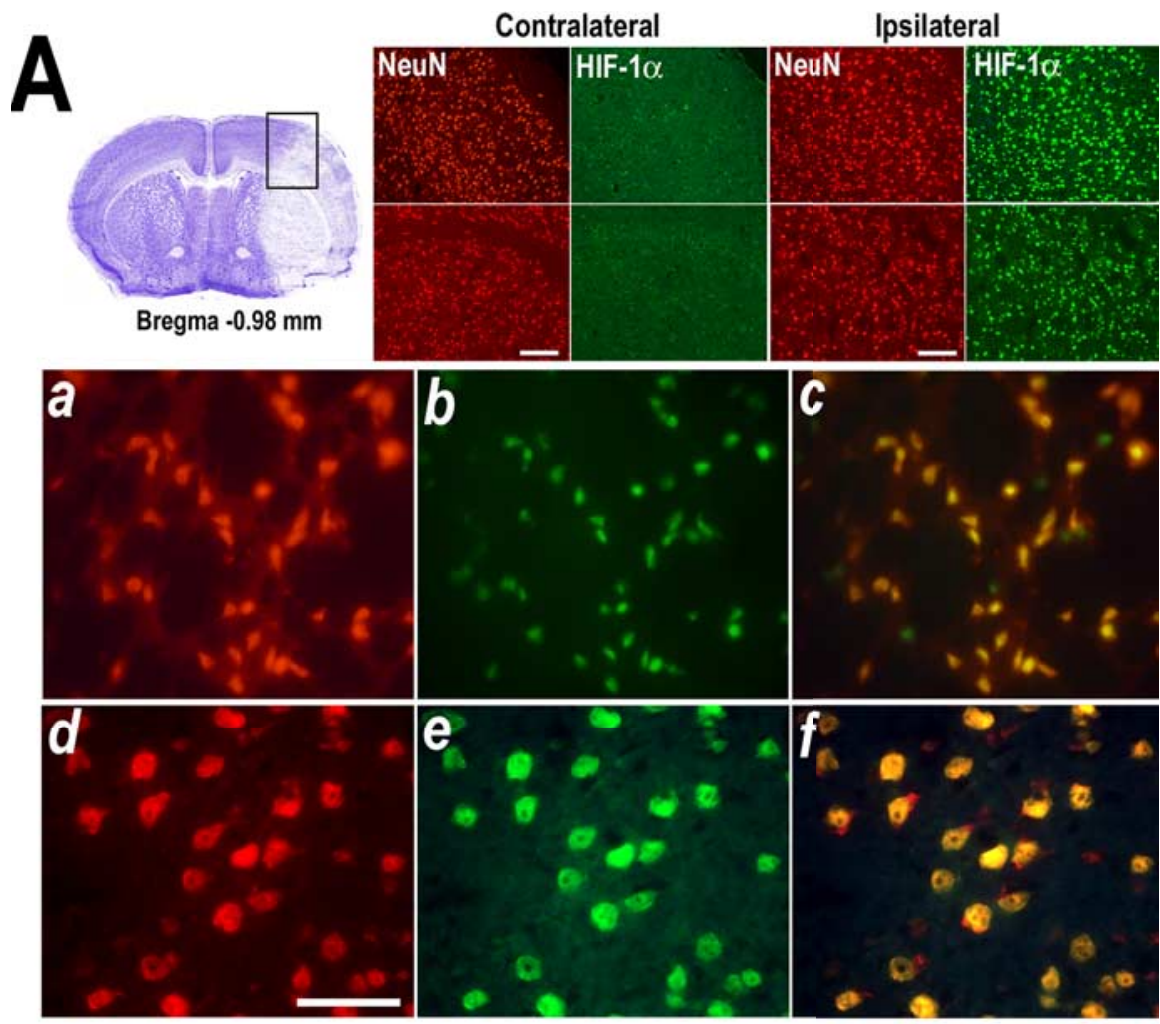

B

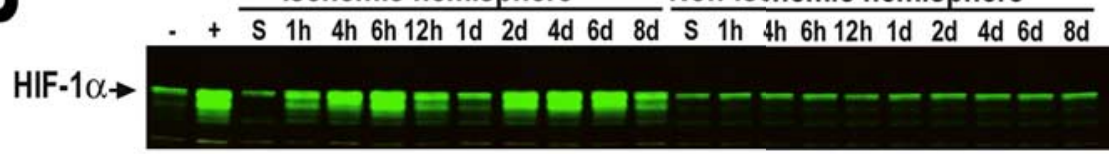

$\alpha$-tubulin $\rightarrow$
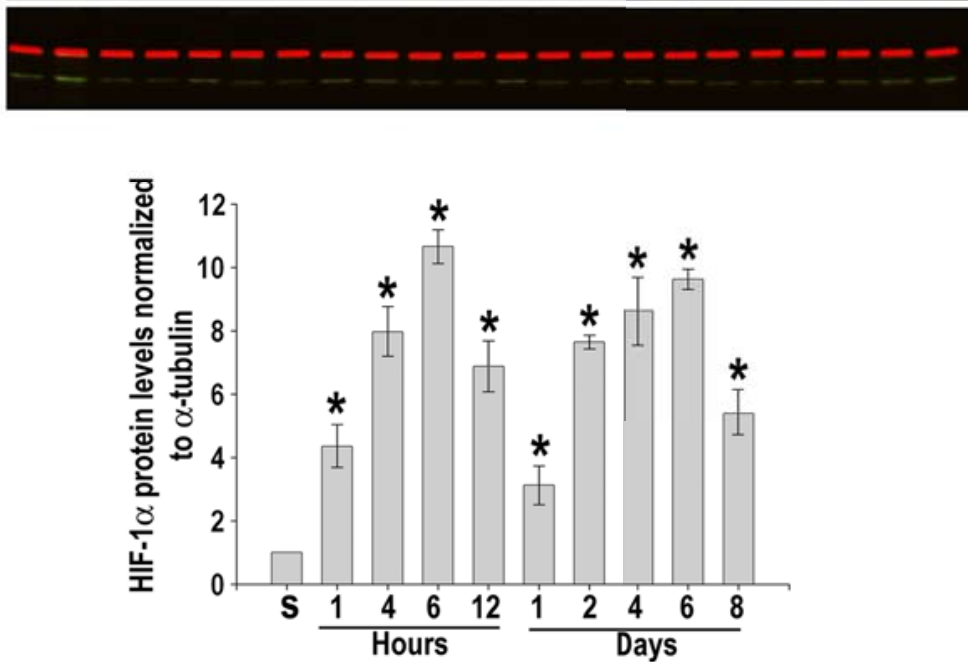

Figure 1. HIF-1 $\alpha$ induction in the mouse brain after transient ischemia. $\boldsymbol{A}$, Double immunostaining of HIF- $1 \alpha$ (green) and $\mathrm{NeuN}$ (red) at $6 \mathrm{~h}$ of recovery from MCAo. Boxed area in cresyl violet-stained section indicates the area in which representative photomicrographs were taken. Top panels show images from cortex and striatum of non-ischemic and ischemic hemispheres. Scale bars, $20 \mu \mathrm{m}$. Bottom panels show higher-magnification views of neurons expressing HIF-1 $\alpha$ that are located in the infarct area $(\boldsymbol{a}-\boldsymbol{c})$ and surrounding tissue $(\boldsymbol{d}-\boldsymbol{f})$. Scale bar, $50 \mu \mathrm{m}$. Merged images are shown in yellow. $\boldsymbol{B}$, Western blot analysis of HIF-1 $\alpha$ in tissue lysates from non-ischemic and ischemic hemisphere of mice subjected to MCAo followed by recovery ( $1 \mathrm{~h}$ to $8 \mathrm{~d}$ ). Codetection of $\alpha$-tubulin was performed to assess equal loading. Nuclear extracts from normoxic and hypoxic cells were used as positive $(+)$ and negative $(-)$ controls, respectively. Protein bands were quantified, and the value obtained from sham-operated control $(S)$ was arbitrarily defined as 1. Graph shows data acquired from four independent experiments. ${ }^{*} p \leq 0.05$ compared with sham. that reached a 10 -fold induction by $6 \mathrm{~h}$. After a transient decline at $1 \mathrm{~d}, \mathrm{HIF}-1 \alpha$ protein expression increased again by $2 \mathrm{~d}$ of recovery (approximately sevenfold) and remained elevated for at least $8 \mathrm{~d}$. In contrast, the constitutive expression of the HIF- $1 \beta$ subunit was not affected by brain ischemia (data not shown).

Generation of mice with neuron-specific knockdown of HIF-1 $\alpha$

Genetic ablation of HIF- $1 \alpha$ at the systemic level results in early embryonic lethality (E10.5) attributable to severe cardiovascular abnormalities among other defects (Iyer et al., 1998). Therefore, to investigate the function of HIF-1 on brain ischemic injury, we used a conditional knockdown approach to inactivate HIF- $1 \alpha$ expression specifically in neurons. This deletion was achieved by crossing mice bearing loxPcontaining (floxed) HIF- $1 \alpha$ alleles (HIF$\left.1 \alpha^{\mathrm{F} / \mathrm{F}}\right)$ with transgenic mice expressing Cre recombinase under control of the CaMKII $\alpha$ promoter. Two independent lines of mice containing the Cre transgene were used, named Rlag\#5 and L7ag\#13 (Dragatsis and Zeitlin, 2000). Neuronspecific expression of Cre recombinase in these lines was demonstrated by crossing each line with ROSA26Sor-LacZ reporter mice. As documented previously, immunostaining analysis showed no obvious differences between R1 and L7 in the pattern of $\beta$-galactosidase expression (data not shown) at 3 weeks of age; both lines demonstrated specific expression of the reporter in a considerable number of neurons throughout the forebrain (Fig. $2 A$ ). As expected, Southern blot analysis showed that, in both lines, the excision of floxed HIF- $1 \alpha$ exon 2 was primarily restricted to forebrain areas without affecting the cerebellum (Fig. 2B). Credependent inactivation of HIF- $1 \alpha$ seems to occur earlier in the L7 line (at approximately E18) compared with R1 (at approximately P5). The majority of $\mathrm{Cre}(+): \mathrm{HIF}-$ $1 \alpha^{\mathrm{F} / \mathrm{F}}$ mice, denoted R1-HIF- $1 \alpha^{\Delta / \Delta}$ or L7-HIF- $1 \alpha^{\Delta / \Delta}$, were born without obvious abnormalities and survived into adulthood. As adults, they had normal body and brain weight and did not show any obvious alteration in behavior and reproductive capacity. Although uncommon, we observed a low rate of hydrocephalus in our colonies (HIF- $1 \alpha^{\mathrm{F} / \mathrm{F}}, n=1$ of 128 animals; R1 - and L7-HIF- $1 \alpha^{\Delta / \Delta}, n=2$ of 98 animals).

Examination of the large cerebral vessels did not show anatomical differences in the circle of Willis (Fig. 3A). However, immunostaining for the vascular marker 
CD31 showed a slight decrease of cerebral microvascular density in L7-HIF- $1 \alpha^{\Delta / \Delta}$ ( $16 \%$ reduction; $p<0.05)$. A similar trend was observed in the R1-HIF- $1 \alpha^{\Delta / \Delta}$ line, but it did not reach statistical significance (Fig. 3B). We should also mention that, despite the decreased microvascular density, Nissl staining revealed that HIF$1 \alpha^{\Delta / \Delta}$ brains seem to have a preserved cytoarchitecture, and terminal deoxynucleotidyl transferase-mediated biotinylated UTP nick end labeling (TUNEL) staining analysis did not show increased basal cell death in untreated animals (data not shown). Importantly, Western blot analysis of cortical lysates showed an expected induction of HIF- $1 \alpha$ protein levels in hypoxic wild-type or HIF- $1 \alpha^{\mathrm{F} / \mathrm{F}}$ mice $(8 \%$ $\mathrm{O}_{2}, 4 \mathrm{~h}$ ); in contrast, this response was severely ablated in the hypoxic HIF- $1 \alpha^{\Delta / \Delta}$ mice (Fig. 2C).

\section{Increased ischemic brain damage in} neuron-specific HIF-1 $\alpha$-deficient mice Preliminary experiments showed similar degrees of brain damage after transient MCAo in wild-type C57BL/6J mice (HIF$1 \alpha^{\mathrm{Wt} / \mathrm{Wt}}$ ) and heterozygote $\mathrm{R} 1$ - or L7HIF- $1 \alpha^{\Delta / \mathrm{Wt}}$ and HIF- $1 \alpha^{\mathrm{F} / \mathrm{F}}$ mice. Therefore, mice with the genotype HIF- $1 \alpha^{\mathrm{F} / \mathrm{F}}$ were used as "control" for most experiments, unless indicated otherwise. As expected, post-ischemic accumulation of HIF- $1 \alpha$ protein was significantly reduced in the HIF- $1 \alpha^{\Delta / \Delta}$ mice compared with controls (Fig. 4A). Residual HIF- $1 \alpha$ expression in the ischemic brain of HIF$1 \alpha^{\Delta / \Delta}$ mice was likely derived from non-neuronal cells or neurons in which Cre-dependent recombination did not take place.

Analysis of the progression of injury after transient MCAo showed comparable infarct size among the HIF- $1 \alpha^{\mathrm{F} / \mathrm{F}}$ and R1and L7-HIF- $1 \alpha^{\Delta / \Delta}$ groups until $\sim 36 \mathrm{~h}$ after MCAo. Afterward, maturation of the infarction reached a plateau in the HIF$1 \alpha^{\mathrm{F} / \mathrm{F}}$ mice but continued in the HIF$1 \alpha^{\Delta / \Delta}$ such that, by day 4 after MCAo, infarct volume was significantly larger compared with the control group ( $35 \%$ increase) (Fig. $4 B$ ). Increased brain damage in HIF- $1 \alpha^{\Delta / \Delta}$ animals was accompanied by higher neurological deficit scores (Fig. 4C). Importantly, survival analysis after transient MCAo showed a comparable probability of survival during the first $4 \mathrm{~d}$ of recovery regardless of the genotype. Thereafter, the survival curves of the HIF$1 \alpha^{\mathrm{F} / \mathrm{F}}$ and HIF- $1 \alpha^{\Delta / \Delta}$ groups clearly began to diverge, with a sharp increase in mortality among HIF- $1 \alpha^{\Delta / \Delta}$ mice (Fig. $4 C$ ). In contrast, a significant proportion of wild-
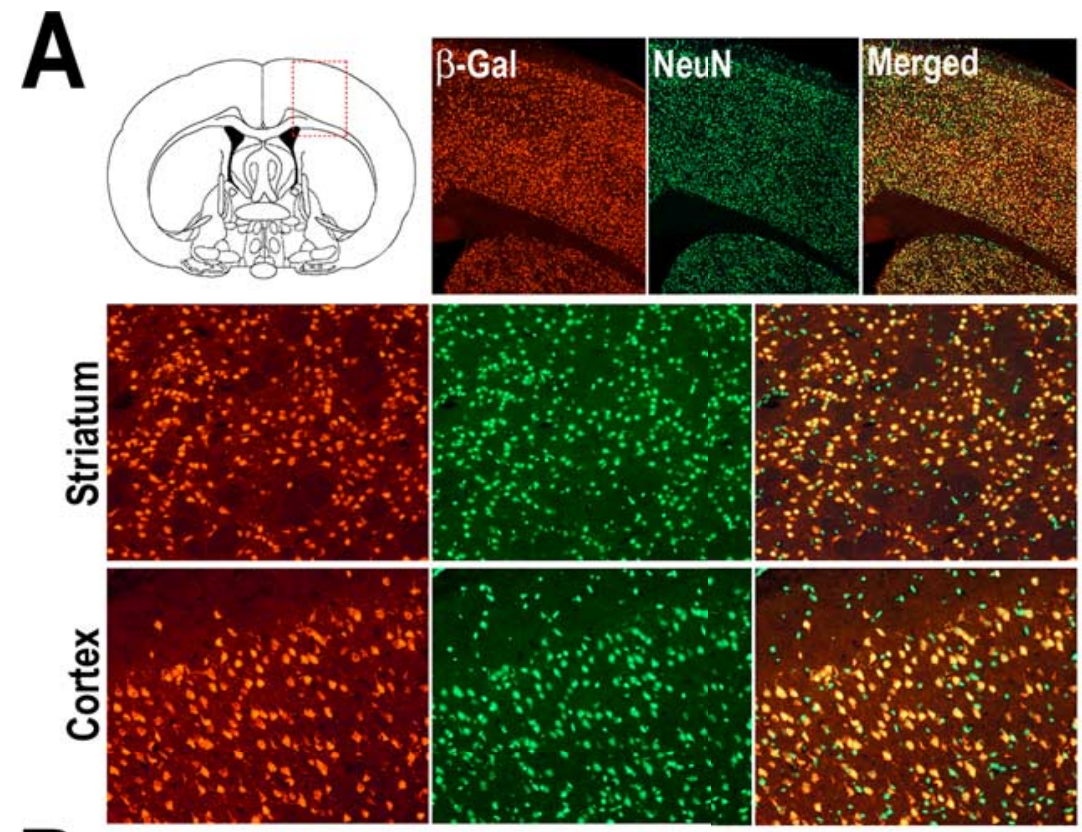

B

Cortex

Striatum

Cerebellum

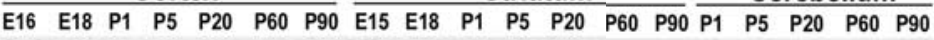
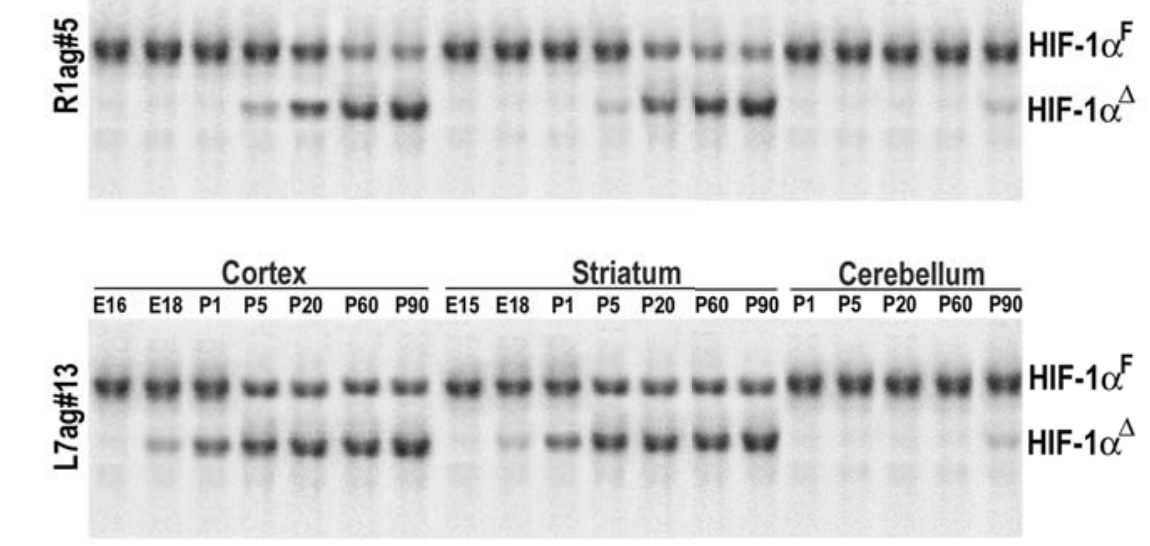

$\mathrm{c}$
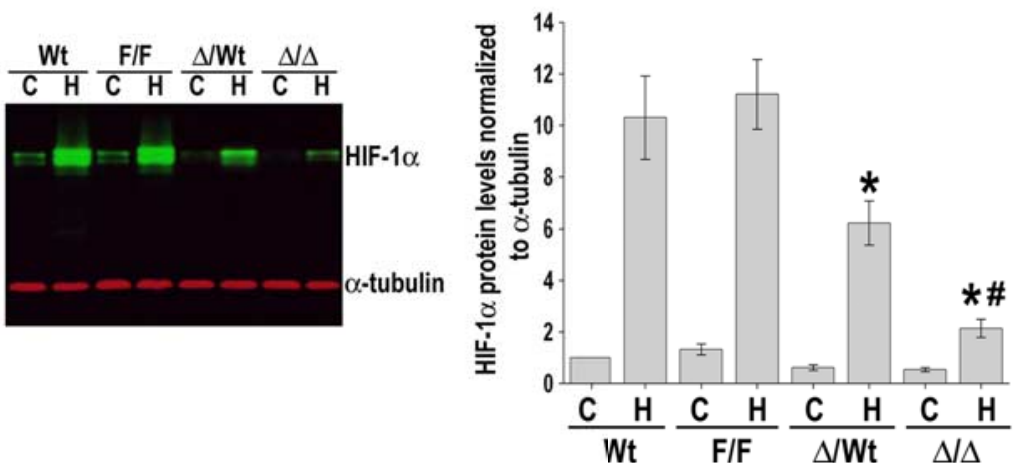

Figure 2. Neuron-specific knockdown of HIF-1 $\alpha$. $\boldsymbol{A}$, Representative microscopic views of boxed area in diagram are shown. CaMKIl $\alpha$-Cre recombinase transgenic line (R1ag\#5) were mated with a LacZ reporter mouse (ROSA26Sor), and brains from offspring (P20) were analyzed by $\beta$-galactosidase staining (red). Double staining with NeuN (green) demonstrated neuronal $\beta$-galactosidase production. Bottom panels show higher-magnification views of the striatum and cortex. $\boldsymbol{B}$, Southern blot analysis was performed on DNA isolated from the cerebral cortex, striatum, and cerebellum of $\mathrm{Cre}(+): \mathrm{HIF}-1 \alpha^{\mathrm{F} / \mathrm{F}}$ mice at indicated ages (E16 to P90), to detect floxed undeleted allele (HIF-1 $\alpha^{\mathrm{F}}$ ) and deleted allele (HIF-1 $\alpha^{\Delta}$ ). C, Decreased cerebral HIF- $1 \alpha$ expression at normoxic $(\mathrm{C})$ and hypoxic $(\mathrm{H})\left(8 \% \mathrm{O}_{2}\right.$ for $\left.4 \mathrm{~h}\right)$ conditions was confirmed in R1-HIF- $1 \alpha^{\Delta / \Delta}$ mice by Western blot analysis. Heterozygous HIF- $1 \alpha^{\Delta / w t}$ also showed a moderate reduction of hypoxic HIF-1 $\alpha$ levels. Data are expressed as the mean \pm SD from four different experiments. ${ }^{*} p \leq 0.05$ versus hypoxic wild-type (Wt-H). ${ }^{*} p \leq 0.05$ versus hypoxic heterozygotes HIF-1 $\alpha^{\Delta / w t}$. 

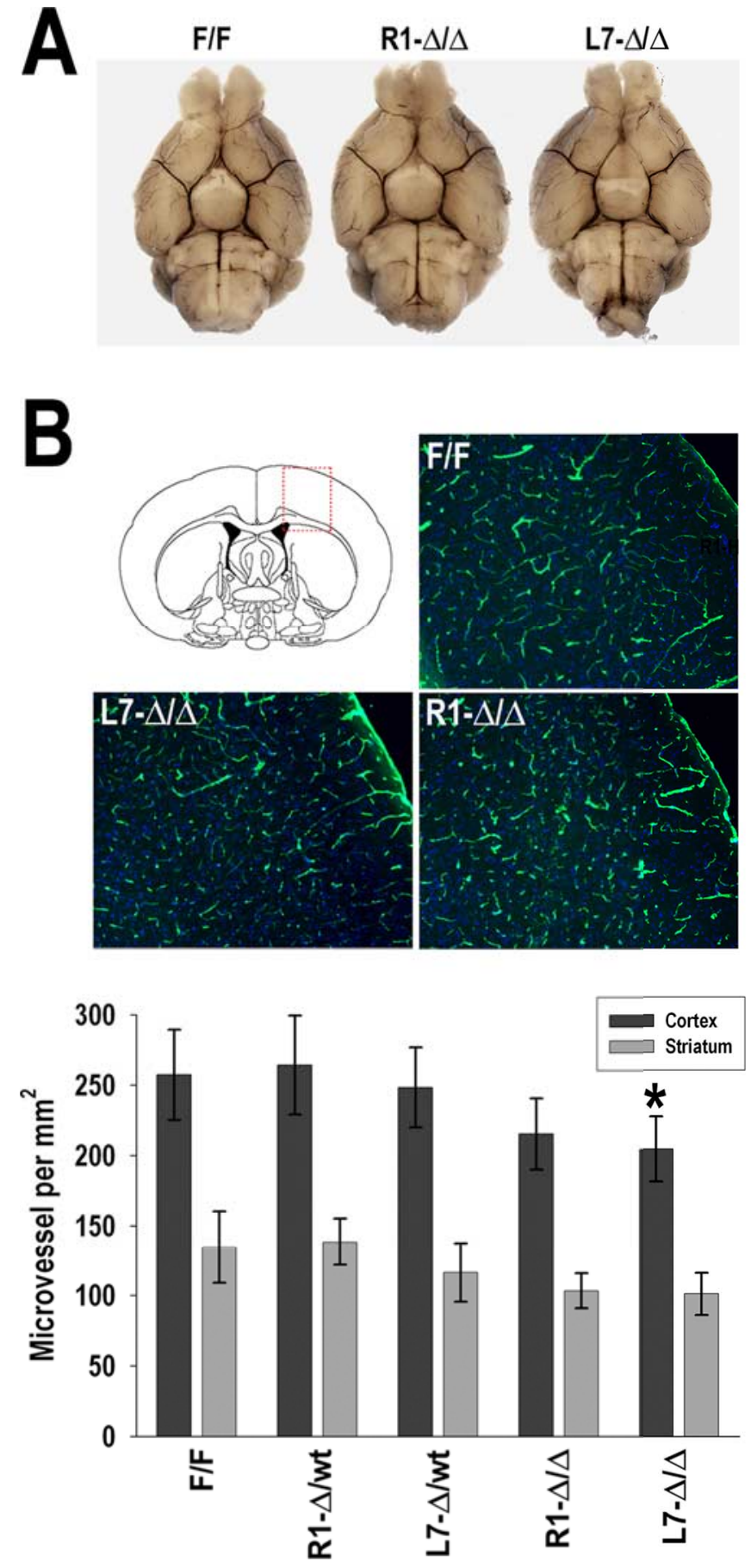

Figure 3. Cerebral vasculature analysis. $\boldsymbol{A}$, Ventral view of large cerebral blood vessels of control (HIF-1 $\alpha^{\mathrm{F} / \mathrm{F}}$ ) and neuronal HIF-1 $\alpha$-deficient (R1- and L7-HIF-1 $\alpha^{\Delta / \Delta}$ ) mice that were perfused with India ink. $\boldsymbol{B}$, Representative microscopic views of boxed area in diagram are shown. Brain sections from HIF- $1 \alpha^{\mathrm{F} / \mathrm{F}}$ and R1- and L7-HIF- $1 \alpha^{\Delta / \Delta}$ mice were immunostained for the endothelial cell-specific marker CD31 (green) for quantification of capillary numbers per area. ${ }^{*} p<0.05$ compared with HIF- $1 \alpha^{\mathrm{F} / \mathrm{F}} ; n=4$.

type mice survived for up to $28 \mathrm{~d}$, and, as expected, they showed a progressive improvement of neurological function.

These results could not be explained by differences between HIF- $1 \alpha^{\Delta / \Delta}$ and HIF- $1 \alpha^{\mathrm{F} / \mathrm{F}}$ in various systemic cardiovascular parameters either before or immediately after the ischemic insult (Table 1). In addition, there were no differences between the control and HIF- $1 \alpha^{\Delta / \Delta}$ groups in local cortical CBF as measured by laser Doppler flowmetry, either during ischemia or the first hour of recovery (Fig. $5 A, B$ ), suggesting normal CBF responses in the cortex in HIF- $1 \alpha^{\Delta / \Delta}$ mice. Importantly, rectal temperature measurements taken at various intervals for up to $4 \mathrm{~d}$ of recovery did not show evidence of hypothermia or hyperthermia in any group (Fig. 5C). Together, these data suggest that neuronal HIF- $1 \alpha$ performs an important role regarding cell survival under ischemic conditions

HIF-1-mediated regulation of proapoptotic and survival/angiogenic factors after brain ischemia Stimulation of several hypoxia-inducible proteins has been described in a variety of cell types of the rodent brain after MCAo (Bergeron et al., 1999; Sharp et al., 2001). However, it has not been established which genes in the ischemic brain are targets of HIF-1, HIF-2, or both. To gain some insight in this issue, we analyzed the response of a set of HIF-regulated genes in the neuronal HIF- $1 \alpha$ knockdown mice (these experiments were performed only in the R1 line). A rapid upregulation of bNIP-3, RTP801, Noxa, and Nix was observed in the ischemic hemisphere of HIF- $1 \alpha^{\mathrm{F} / \mathrm{F}}$ animals (Fig. $6 A, B$ ). At the mRNA and protein level, the induction of these proapoptotic genes peaked at $6-12 \mathrm{~h}$ after MCAo and declined to non-ischemic levels by 1-2 d of recovery. In comparison, the expression of these genes was drastically attenuated in the ischemic brains of HIF- $1 \alpha^{\Delta / \Delta}$ mice (Fig. $6 B$ ). In addition, we analyzed the response of genes with established roles in neuronal survival and/or vascular biology, namely Epo, Glut-1, enolase, Vegf, Flt-1, Flk-1, PAI-1, and Ang-2 (Fig. 7). Real-time reverse transcription (RT)-PCR analysis showed that mRNA levels of all these genes were significantly increased after MCAo in HIF- $1 \alpha^{\mathrm{F} / \mathrm{F}}$ brains, and, in most cases, this response lasted for several days after the insult. With the exception of Epo and Flk-1, post-ischemic stimulation of these genes was attenuated in HIF- $1 \alpha^{\Delta / \Delta}$ mice (Fig. 7). Notably, in the mutant HIF$1 \alpha^{\Delta / \Delta}$ mice, the basal levels of Epo and Flk-1 were higher compared with wild-type mice, and their upregulation after brain ischemia was preserved (Fig. 7). These results are in accordance with previous reports indicating that hypoxic expression of Epo and Flk-1 is restricted to endothelial and glial cells, in which HIF-1 activity is preserved, because it is unlikely that Cre expression driven by the CaMKII $\alpha$ promoter occurs. Furthermore, the expression of Epo and Flk-1 might be controlled by HIF-2 rather than HIF-1 (Elvert et al., 2003; Chavez et al., 2006).

\section{Lesser severity of brain ischemia damage by treatment with} pharmacologic HIF-1 activators

Inhibitors of prolyl hydroxylases have been tested recently for their ability to induce HIF- $1 \alpha$ stabilization and subsequent expression of target genes in cultured cells as well as in vivo (Warnecke et al., 2003; Demougeot et al., 2004). Among them, previous reports indicated that 3,4-dihydroxybenzoic acid, deferoxamine (DFO), and DP have neuroprotective effects against brain ischemia (Demougeot et al., 2004; Van Hoecke et al., 2005; Siddiq et al., 2005; Freret et al., 2006). However, it is unclear whether these agents act solely on the HIF pathway. In agreement with previous reports, we found that administration of these compounds, at the doses used for our neuroprotection experiments, led to significant accumulation of HIF- $1 \alpha$ protein in the cerebral cortex at $6 \mathrm{~h}$ after drug delivery $(\sim 8$ - to 10 -fold increase) (Fig. $8 \mathrm{~A}$ ). This was accompanied by a significant upregulation of Vegf and Glut-1 mRNA levels at $24 \mathrm{~h}$ after administration (approximately threefold increase), indicating a functional activation of the HIF-1 complex in the cerebral cortex. Importantly, delivery of these drugs into HIF- $1 \alpha^{\Delta / \Delta}$ mice did not 
A

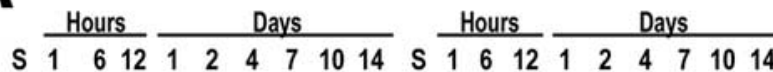

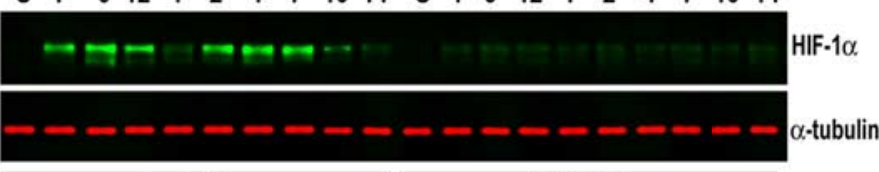

FIF R1- $\Delta / \Delta$
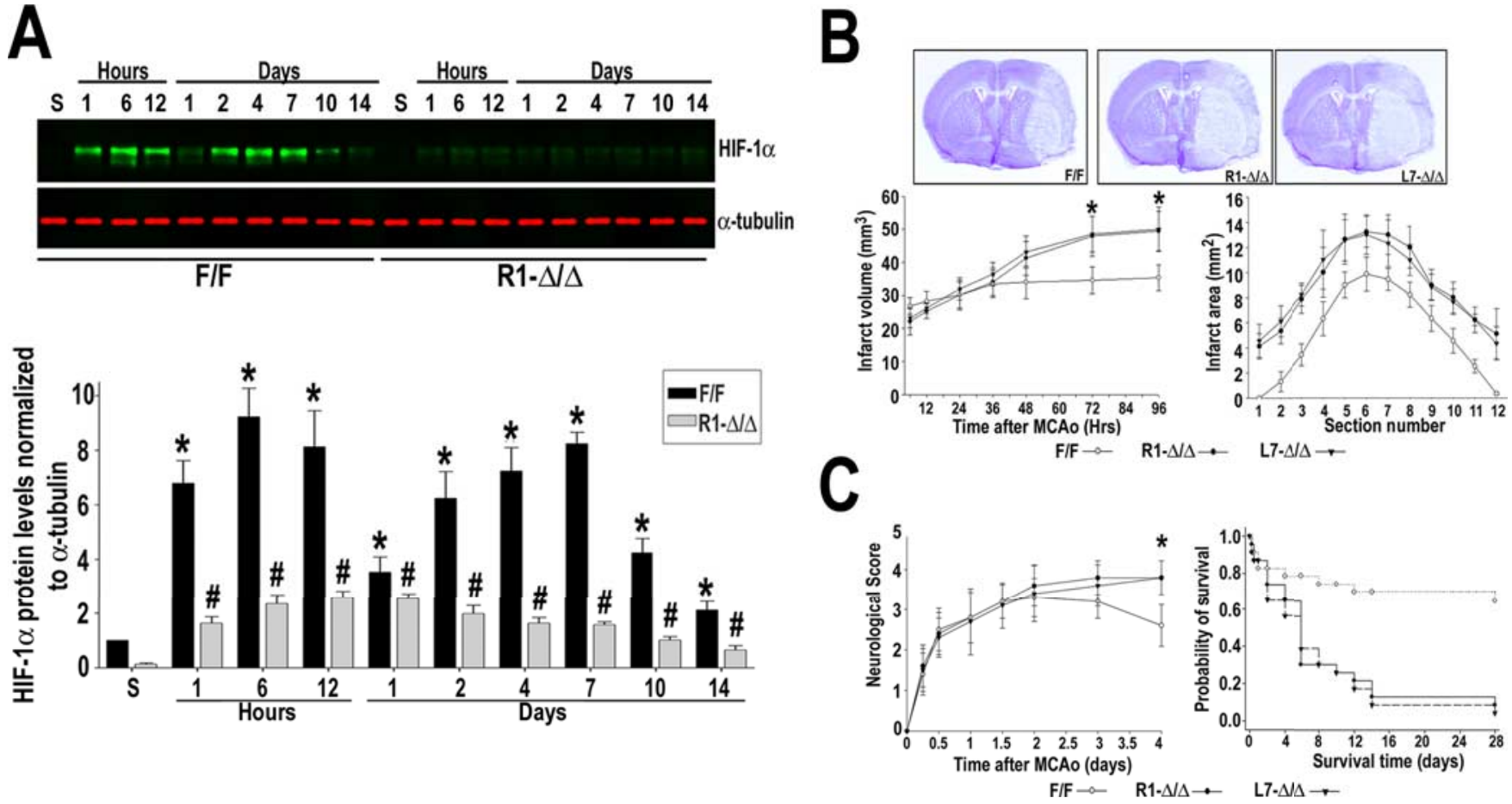

Figure 4. Role of neuronal HIF-1 $\alpha$ in ischemic brain injury. $\boldsymbol{A}$, Immunoblot analysis of HIF- $1 \alpha$ in the ischemic hemisphere of R1-HIF-1 $\alpha^{\Delta / \Delta}$ and control (HIF-1 $\alpha^{\mathrm{F} / \mathrm{F}}$ ) mice subjected to transient MCAo and recovery ( $1 \mathrm{~h}$ to $14 \mathrm{~d}$ ). Codetection of $\alpha$-tubulin was performed to assess equal loading. Protein bands were quantified, and the value obtained from sham-operated control (S) was arbitrarily defined as $1 ; n=5$. $^{*} p<0.05$ versus sham HIF- $1 \alpha^{\mathrm{F} / \mathrm{F}} ;{ }^{\#} p<0.05$ versus sham HIF- $1 \alpha^{\Delta / \Delta}$. B, Evolution of the infarct volume was assessed at different time points of recovery after MCA0 in the following genotypes: HIF- $1 \alpha^{\mathrm{F} / \mathrm{F}}$ and R1- and L7-HIF- $1 \alpha^{\Delta / \Delta}$. At $4 \mathrm{~d}$ of recovery, infarct area was measured in 12 sequential sections taken at rostral to caudal regular intervals. Representative sections stained with cresyl violet are shown from the indicated genotypes at $4 \mathrm{~d}$ of recovery. C, Blinded scoring of neurological deficit was assessed at different time points of recovery in $\mathrm{HIF}-1 \alpha$ F/F and R1- and L7-HIF-1 $\alpha^{\Delta / \Delta}$. Kaplan-Meier survival analysis after transient MCAo in the indicated mouse genotypes. In $\boldsymbol{B}$ and $\boldsymbol{C}$, at least 23 mice per genotype are represented in the neurological score and survival curves. ${ }^{*} p<0.05$ compared with HIF- $1 \alpha^{\mathrm{F} / \mathrm{F}}$.

Table 1. Physiological parameters measured $45 \mathrm{~min}$ before and $45 \mathrm{~min}$ after MCAo in wild-type (HIF-1 $\alpha^{\mathrm{F} / \mathrm{F}}$ ) and neuron-specific HIF-1 $\alpha$ null (HIF-1 $\alpha^{\Delta / \Delta}$ ) mice

\begin{tabular}{|c|c|c|c|c|c|c|}
\hline \multirow[b]{2}{*}{ Parameter } & \multicolumn{2}{|l|}{ HIF- $1 \alpha^{\mathrm{F} / \mathrm{F}}$} & \multicolumn{2}{|l|}{ R1-HIF-1 $\alpha^{\Delta / \Delta}$} & \multicolumn{2}{|l|}{ L7-HIF-1 $\alpha^{\Delta / \Delta}$} \\
\hline & Pre-MCAo & Post-MCAo & Pre-MCA0 & Post-MCAo & Pre-MCAo & Post-MCAo \\
\hline $\operatorname{MABP}(\mathrm{mmHg})$ & $70.0 \pm 2.1$ & $61.4 \pm 3.3$ & $69.1 \pm 3.8$ & $61.6 \pm 3.1$ & $69.1 \pm 3.8$ & $61.6 \pm 3.1$ \\
\hline Heart rate (per min) & $412.3 \pm 16.2$ & $403.6 \pm 15.6$ & $421.4 \pm 15.3$ & $432.5 \pm 12.4$ & $413.9 \pm 9.7$ & $431.4 \pm 18.1$ \\
\hline Glucose (mg/dl) & $175.3 \pm 10.5$ & $209.5 \pm 12.9$ & $181.7 \pm 11.4$ & $221.3 \pm 23.4$ & $183.6 \pm 11.2$ & $215.9 \pm 18.4$ \\
\hline \multicolumn{7}{|l|}{ Arterial $\mathrm{pCO}$} \\
\hline$(\mathrm{mmHg})$ & $58.6 \pm 3.2$ & $55.3 \pm 3.5$ & $57.8 \pm 4.7$ & $53.4 \pm 4.3$ & $57.9 \pm 6.3$ & $52.8 \pm 3.8$ \\
\hline \multicolumn{7}{|l|}{ Arterial $\mathrm{pO}$} \\
\hline$(\mathrm{mmHg})$ & $79.56 \pm 5.4$ & $75.4 \pm 7.2$ & $76.2 \pm 5.9$ & $72.5 \pm 9.2$ & $73.5 \pm 8.4$ & $70.8 \pm 6.5$ \\
\hline $\mathrm{pH}$ & $7.21 \pm 0.15$ & $7.18 \pm 0.09$ & $7.23 \pm 0.11$ & $7.19 \pm 0.13$ & $7.15 \pm 0.08$ & $7.24 \pm 0.14$ \\
\hline $\mathrm{Hb}$ (g/liter) & $14.8 \pm 1.2$ & $14.1 \pm 0.9$ & $15.1 \pm 1.2$ & $14.7 \pm 0.9$ & $14.5 \pm 1.1$ & $14.1 \pm 0.7$ \\
\hline Body weight (g) & $30 \pm 2$ & & $28.5 \pm 2$ & & $29 \pm 3$ & \\
\hline
\end{tabular}

None of the parameters analyzed were significantly different among groups (one- way ANOVA). Indicated values are expressed as mean \pm SD; $n=5$ for each group. MABP, Mean arterial blood pressure; Hb, hemoglobin concentration.

lead to a significant upregulation of Vegf or Glut-1 mRNA (Fig. $8 B)$.

To determine whether the protective effects of these compounds require neuronal HIF-1 activity, HIF- $1 \alpha^{\mathrm{F} / \mathrm{F}}$ and HIF$1 \alpha^{\Delta / \Delta}$ mice were treated $6 \mathrm{~h}$ before the onset of MCAo (pretreatment) or $6 \mathrm{~h}$ after ischemia (posttreatment). Subsequently, infarct volume was assessed at $4 \mathrm{~d}$ of recovery. In the case of HIF- $1 \alpha^{\mathrm{F} / \mathrm{F}}$ mice, both treatment modalities were effective in reducing the ischemic lesion. However, the neuroprotection achieved by pretreatment was more robust compared with posttreatment. The reduction of infarction achieved with the pretreatment modality was $35 \pm 5 \%$ for DP, $41 \pm 5 \%$ for DHB, and $25 \pm 5 \%$ for DFO. For the posttreatment modality, the reduction achieved was $21 \pm 5 \%$ for DP, $28 \pm 5 \%$ for DHB, and $15 \pm 5 \%$ for DFO (Fig. $8 C$ ). In contrast, the protective effect of these drugs administered either before or after MCAo was reduced in the HIF- $1 \alpha^{\Delta / \Delta}$ mice, indicating that their salubrious effects were in part mediated by HIF-1 activation.

Protective effect of hypoxic preconditioning against ischemic brain damage despite inactivation of neuronal HIF-1 $\alpha$

It has been documented that exposure to sublethal hypoxia before cerebral ischemia reduces subsequent brain damage (Bernaudin et al., 2002a; Sharp et al., 2004; Gidday, 2006). The transcription factor HIF-1 was reasonably predicted to participate in the protective effect of hypoxic preconditioning by promoting activation of endogenous adaptive pathways (Bernaudin et al., 2002a; Ran et al., 2005). To test this hypothesis, we studied the effects of hypoxic preconditioning $\left(8 \% \mathrm{O}_{2}\right.$ for $\left.0-4 \mathrm{~h}\right)$, performed $24 \mathrm{~h}$ before transient MCAo, on ischemic brain damage in control 

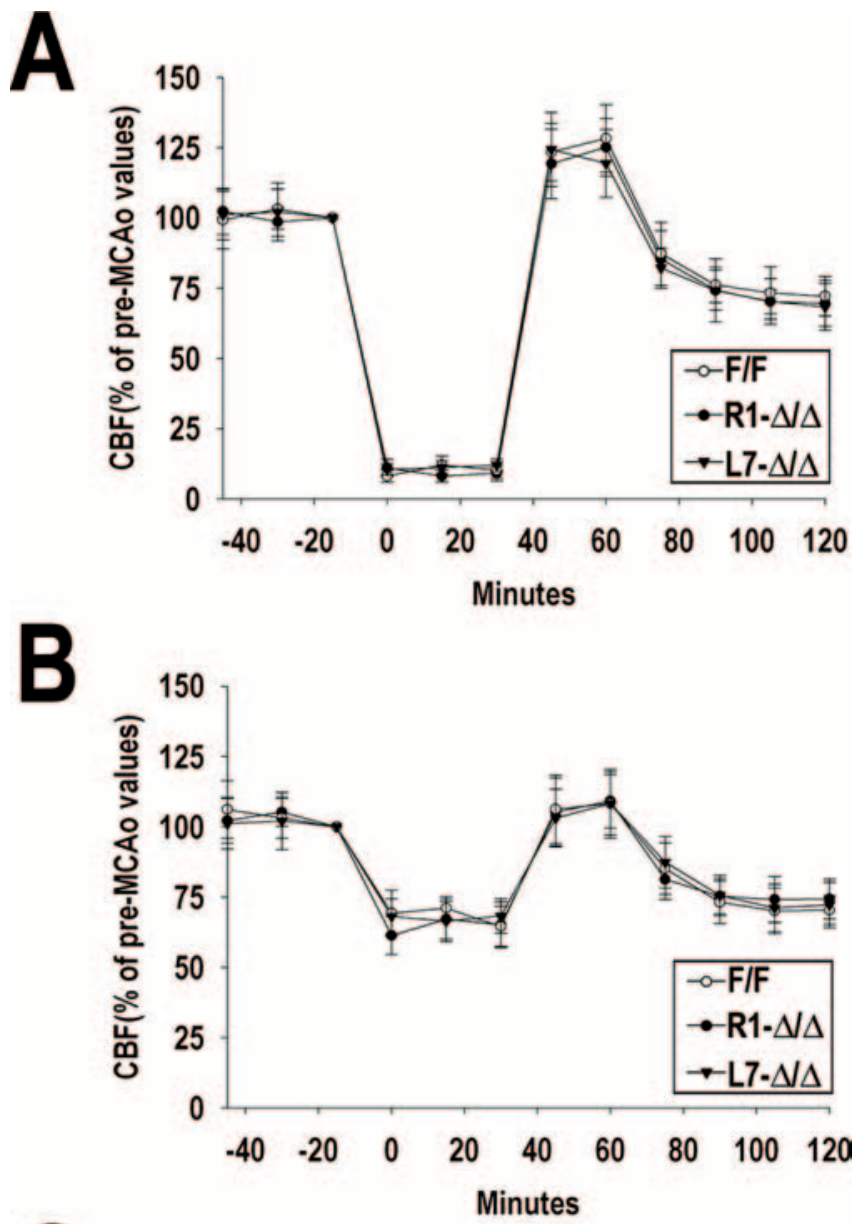

C

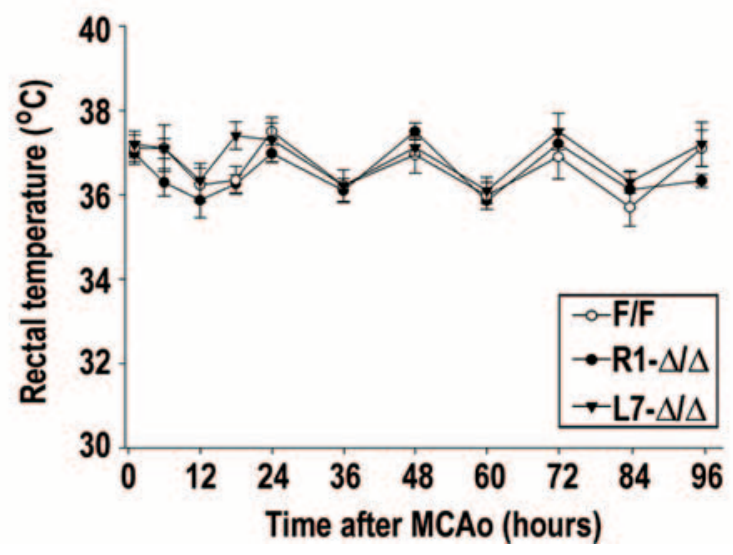

Figure 5. Cerebral blood flow and rectal temperature after MCAo. Local CBF was monitored before, during MCA0, and after reperfusion by laser Doppler flowmetry. Graphs indicate CBF monitored at the ischemic area $(\boldsymbol{A})$ and the periphery $(\boldsymbol{B})$. Pre-ischemic values were arbitrarily defined as $100 \%$. Rectal temperature (degrees Celsius) was measured using a rectal probe at $12 \mathrm{~h}$ intervals for up to $4 \mathrm{~d}$ after ischemia (C). Data are expressed as mean \pm SD from 8-10 animals per genotype.

and neuronal HIF- $1 \alpha$-deficient mice. A parallel set of animals were exposed to normoxia conditions $\left(21 \% \mathrm{O}_{2}, 0-4 \mathrm{~h}\right) 24 \mathrm{~h}$ before MCAo. In wild-type or HIF- $1 \alpha^{\mathrm{F} / \mathrm{F}}$ animals, $4 \mathrm{~h}$ of hypoxic preconditioning reduced infarct volume $(\sim 25 \%$ reduction at $4 \mathrm{~d}$ of recovery) when compared with animals exposed to normoxia. Shorter periods of hypoxia were less effective in reducing ischemic brain damage (Fig. 9). Contrary to our expectations, hypoxic preconditioning $(2-4 \mathrm{~h})$ consistently reduced infarct vol-
A

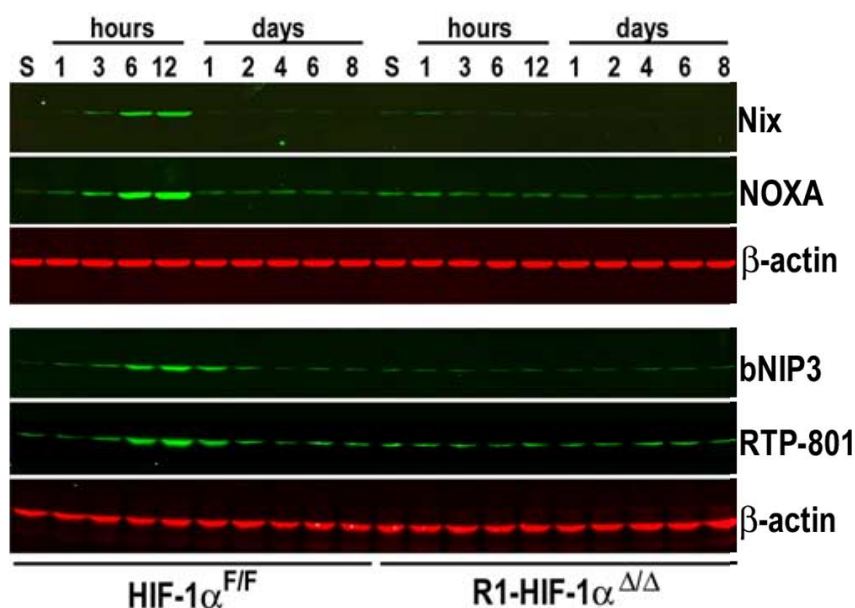

B

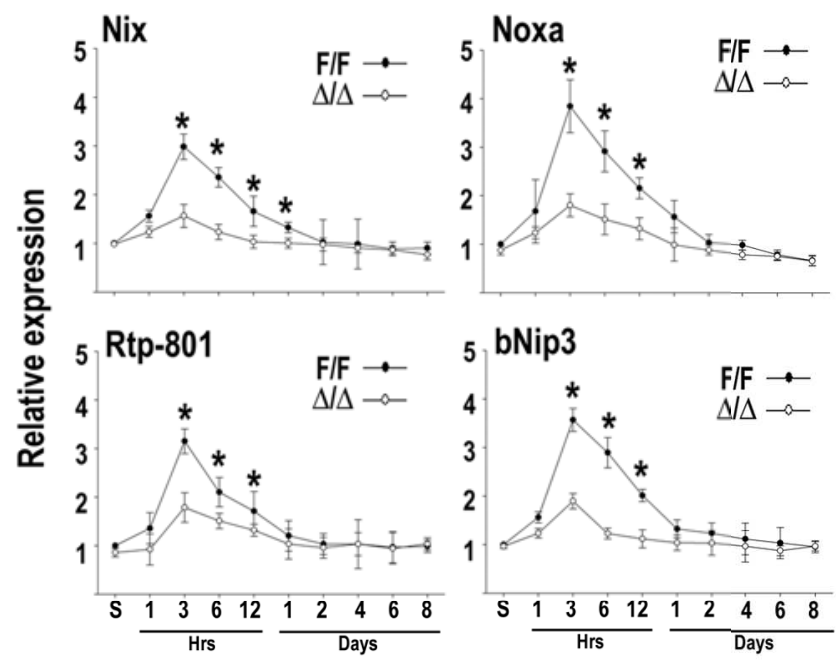

Time after re-perfusion

Figure 6. HIF-1-dependent expression of proapoptotic mediators after brain ischemia. $\boldsymbol{A}$, Western blot analysis of the indicated proteins in the ischemic hemisphere of $\mathrm{HIF}-1 \alpha^{\mathrm{F} / \mathrm{F}}$ and R1-HIF-1 $\alpha^{\Delta / \Delta}$ mice. Animals were subjected to transient MCAo and killed at different periods of recovery ( $1 \mathrm{~h}$ to $8 \mathrm{~d}$ ). $\boldsymbol{B}$, Real-time RT-PCR analysis of the indicated genes in the ischemic hemisphere of HIF-1 $\alpha^{\mathrm{F} / \mathrm{F}}$ (filled circles) and R1-HIF- $1 \alpha^{\Delta / \Delta}$ (open circles) mice. Data were normalized to $\beta$-actin and expressed relative to $\mathrm{HIF-} 1 \alpha^{\mathrm{FF}}$ sham control (S), which was arbitrarily defined as 1 . Data are expressed as mean \pm SD from five animals per genotype. ${ }^{*} p<$ 0.05 versus sham.

ume in HIF- $1 \alpha^{\Delta / \Delta}$ mice at $4 \mathrm{~d}$ of recovery $(\sim 38 \%$ reduction) (Fig. 9). Interestingly, both R1- and L7-HIF-1 $\alpha^{\Delta / \Delta}$ mice required shorter hypoxic exposure to produce significant reduction of infarct volumes compared with wild-type mice (Fig. 9).

A potential mechanism that could account for these unexpected results could be related to a compensatory increased expression of HIF- $2 \alpha$ in HIF- $1 \alpha^{\Delta / \Delta}$ brains. Indeed, even basal protein levels of HIF- $2 \alpha$ and its target Epo were found to be augmented in HIF- $1 \alpha^{\Delta / \Delta}$ brains. Levels of both proteins were further enhanced after exposure of HIF-1 $1 \alpha^{\Delta / \Delta}$ mice to hypoxia $\left(8 \% \mathrm{O}_{2}\right.$ for $\left.4 \mathrm{~h}\right)$ (Fig. $\left.10 A, B\right)$. 


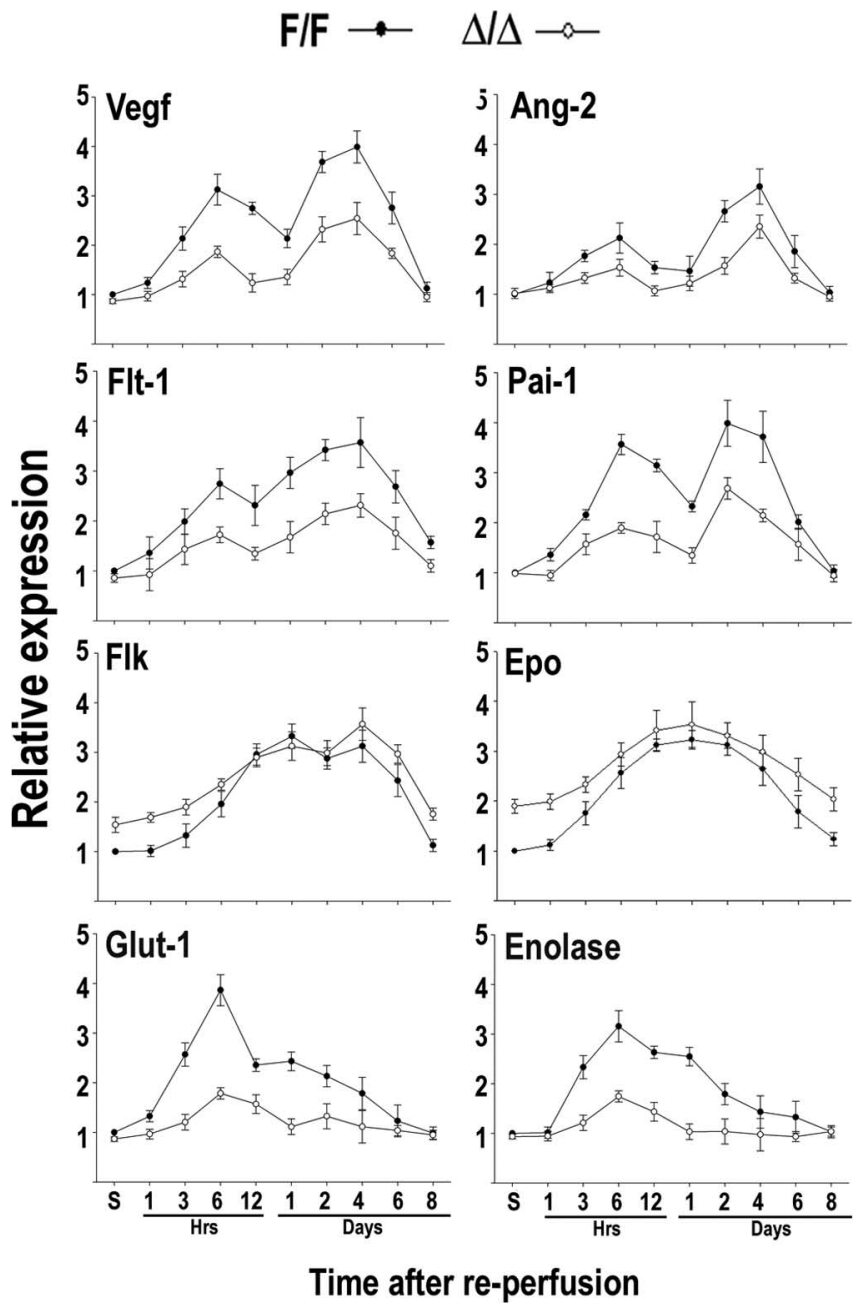

Figure 7. Expression of HIF-regulated genes in the ischemic brain. Real-time RT-PCR analysis of the indicated genes in the ischemic hemispheres of HIF- $1 \alpha^{\mathrm{F} / \mathrm{F}}$ (filled circles) and R1-HIF$1 \alpha^{\Delta / \Delta}$ (open circles) mice. Animals were subjected to transient focal ischemia and killed at different times of recovery ( $1 \mathrm{~h}$ to $8 \mathrm{~d}$ ). Data were normalized to $\beta$-actin and expressed relative to HIF-1 $\alpha^{\mathrm{F} / \mathrm{F}}$ sham control (S), which was arbitrarily defined as 1. Data are expressed as mean \pm SD from five animals per genotype.

\section{Discussion}

The role of the transcriptional activator HIF-1 in neuronal survival during or after an ischemic insult has been a matter of controversy. Evidence for both a pro-death and a beneficial role of HIF- $1 \alpha$ have been reported in a variety of cellular and in vivo models of ischemia. To gain insight into the role of HIF- $1 \alpha$ in the pathophysiology of stroke, we used a well established model of focal cerebral ischemia induced by MCAo in mutant mice with neuron-specific conditional knockdown of HIF- $1 \alpha$. These HIF$1 \alpha^{\Delta / \Delta}$ mice were generated by crossing animals carrying HIF- $1 \alpha$ floxed alleles with two independent CaMKII $\alpha$-Cre transgenic lines. Our data reveal that MCAo triggered a robust and longlasting HIF- $1 \alpha$ protein accumulation that was mainly restricted to neurons in the ischemic hemisphere. Activation of HIF-1 appears to have an overall beneficial role in the ischemic brain as indicated by increased brain damage and reduced survival rate of HIF- $1 \alpha^{\Delta / \Delta}$ mice compared with wild-type animals subjected to transient MCAo. In addition, we showed that HIF- $1 \alpha^{\Delta / \Delta}$ mice maintained their ability to develop ischemic tolerance as a result of hypoxic preconditioning, indicating that neuronal HIF- $1 \alpha$ does not play a role in this paradigm. Furthermore, we demon- strated that the neuroprotective efficacy of pharmacologic inhibitors of HIF prolyl hydroxylases was not entirely but heavily dependent on their ability to activate HIF-1 because their salubrious effects were significantly attenuated in $\operatorname{HIF}-1 \alpha^{\Delta / \Delta}$ mice.

The first phase of HIF- 1 activation occurred before $24 \mathrm{~h}$ postocclusion; after a transient decline at $24 \mathrm{~h}, \mathrm{HIF}-1 \alpha$ protein levels increased again and remained elevated for at least $8 \mathrm{~d}$. This initial phase correlated with the upregulation of various HIF target genes encoding glycolytic enzymes, pro-angiogenic proteins, and pro-death modulators. In the second phase of HIF-1 activation, none of the analyzed pro-death genes (bNIP3, Noxa, Nix, and RTP801) remained significantly elevated, whereas the expression of genes implicated in angiogenesis (Vegf, Flt-1, PAI-1, Ang-2, and Flk) continued to be substantially higher in the ischemic hemisphere. The expression of other HIF target genes, such as Glut-1, enolase, and Epo, also remained elevated. It is possible that, during the acute phase after ischemia ( $<24 \mathrm{~h}$ recovery), HIF- $1 \alpha$ may contribute to cell death in part through the transcriptional upregulation of proapoptotic target genes. However, this deleterious response was accompanied and superseded by a long-lasting expression of genes encoding proteins that mediate protective and/or regenerative responses (i.e., Epo and Vegf). Consistent with this view, HIF- $1 \alpha^{\Delta / \Delta}$ mice displayed a smaller number of TUNEL-positive cells at 1,6 , and $12 \mathrm{~h}$ after occlusion in cortical and striatal areas adjacent to the ischemic core compared with wild-type mice (data not shown). During this period, the extent of the infarction was slightly smaller in the HIF-1 $\alpha^{\Delta / \Delta}$ mice, but this difference was not statistically significant. Although by $24 \mathrm{~h}$ of recovery infarct volumes were comparable between HIF- $1 \alpha^{\Delta / \Delta}$ and wild-type mice, the HIF- $1 \alpha^{\Delta / \Delta}$ mice developed significantly larger infarcts beginning at $36 \mathrm{~h}$ after MCAo. This increased infarct maturation in the HIF- $1 \alpha^{\Delta / \Delta}$ mice was associated with a severe neurological deficit and a sharp increase in mortality after day 4 of recovery.

The enhanced tissue damage in the HIF- $1 \alpha^{\Delta / \Delta}$ mice could not be attributed to changes in systemic physiologic parameters under basal conditions or at $1 \mathrm{~h}$ after MCAo. More importantly, rectal temperature measurements after MCAo indicated that HIF- $1 \alpha^{\Delta / \Delta}$ mice did not display systemic hyperthermia that could explain the increased infarction. Because we were not able to monitor continuously systemic or cerebral temperature, we could not rule out the possibility that these animals developed transient febrile episodes that might have enhanced tissue damage. However, we consider this an unlikely possibility because, in a small cohort of R1-HIF- $1 \alpha^{\Delta / \Delta}$ mice $(n=3)$ that received acetaminophen after MCAo (every $8 \mathrm{~h}$ for up to $4 \mathrm{~d}$ ) to minimize fever, the infarct volumes were still larger than wild-type mice subjected to the same treatment (data not shown).

An important consideration for the interpretation of our data are the fact that both HIF- $1 \alpha^{\Delta / \Delta}$ lines showed a reduced capillary density in the cortex and striatum, although the magnitude of these changes reached statistical significance only in the L7 line in which Cre-dependent excision of HIF- $1 \alpha$ exon 2 was detected earlier (E18 compared with P5 in R1 line). This phenotype implicates neuronal HIF-1 in the regulation of the angiogenic process occurring during brain development and certainly may contribute to the greater ischemic injury found in the adult HIF- $1 \alpha^{\Delta / \Delta}$ mice after transient MCAo. For instance, this reduced microvasculature could alter local perfusion in the tissues surrounding the infarct core leading to a chronic low-grade ischemia that would certainly worsen the infarct in a progressive manner. In this regard, we analyzed CBF using laser Doppler probes that allow 
A
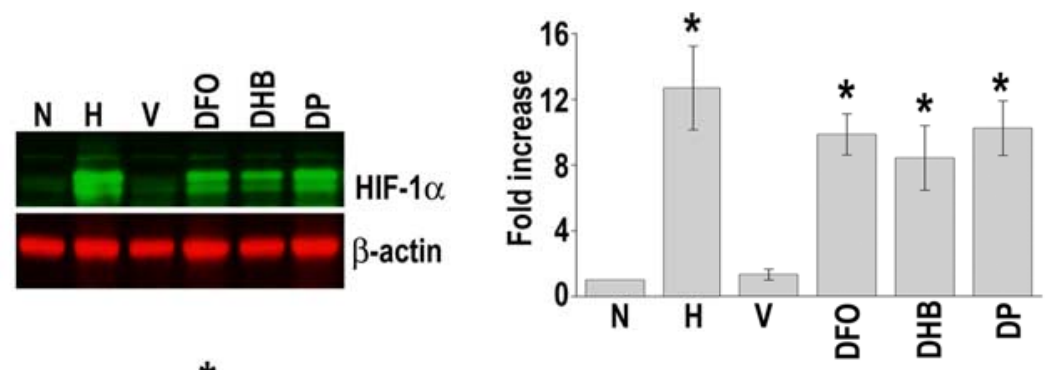

B

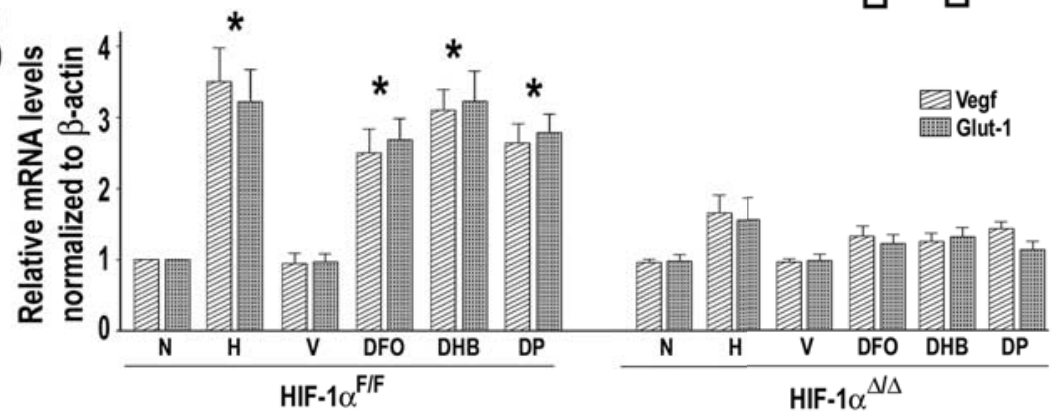

C
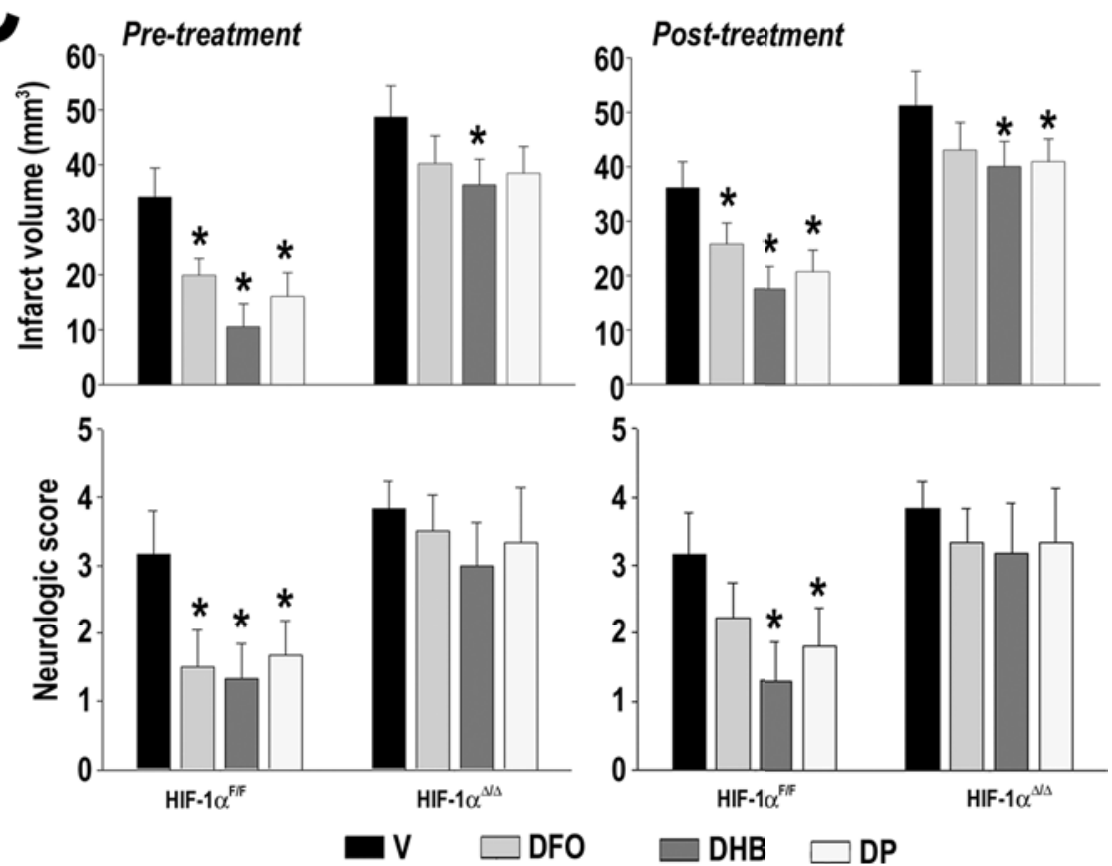

Figure 8. Effect of prolyl hydroxylases inhibitors on ischemic brain damage. $\boldsymbol{A}$, Western blot analysis of HIF-1 $\alpha$ in brain cortex of animals treated with vehicle intraperitoneally (V), DP (20 mg/kg, i.p.), DHB (200 mg/kg, i.p.), and DF0 (300 mg/kg, s.c.). Animals were killed $6 \mathrm{~h}$ after drug administration. Normoxic $(\mathrm{N})$ and hypoxic $(\mathrm{H})\left(8 \% \mathrm{O}_{2}\right.$ for $\left.4 \mathrm{~h}\right)$ animals were used for comparison. $\boldsymbol{B}$, RT-PCR analysis of Vegf and Glut-1 in brain cortex at $24 \mathrm{~h}$ after treatment of animals (HIF-1 $\alpha^{\mathrm{F} / \mathrm{F}}$ and R1-HIF-1 $\alpha^{\Delta / \Delta}$ ) as indicated in $\boldsymbol{A}$. C, Pretreatment of HIF-1 $\alpha^{\mathrm{F} / \mathrm{F}}$ and R1-HIF-1 $\alpha^{\Delta / \Delta}$ mice with the indicated drugs was performed $6 \mathrm{~h}$ before the ischemic insult, and posttreatment began $6 \mathrm{~h}$ after MCAo. Evaluation of infarct volume and neurological deficit was made $4 \mathrm{~d}$ after the onset of ischemia. Data are presented as mean \pm SD $(n=6) .{ }^{*} p \leq 0.05$ compared with normoxia (N) or vehicle (V).

cortex do not differ among HIF- $1 \alpha^{\Delta / \Delta}$ and wild-type mice during the recovery phase of the ischemic insult, the differential progression of the infarction might be attributable to a truly reduced neuroprotective response in HIF- $1 \alpha$-deficient neurons.

It is well documented that, besides astrocytes and endothelial cells, neurons can also express some pro-angiogenic proteins such as VEGF and angiopoietins not only during development but also in the adult ischemic brain (Hayashi et al., 1997; Jin et al., 2000; Lin et al., 2000, 2001; Ogunshola et al., 2000; Marti et al., 2000). Thus, it is possible that the significant reduction in the expression of several pro-angiogenic molecules in the HIF- $1 \alpha^{\Delta / \Delta}$ ischemic brain could be attributed to a reduction of neuronal HIF-1 activity. Alternatively, it is tempting to speculate that, in the ischemic brain, a crosstalk between neurons and non-neuronal cells regulates a coordinated angiogenic response in a way that inactivation of HIF-1 in neurons can indirectly affect the production of angiogenic mediators by other cell types. We should also note that, although we found that the activity of Cre recombinase in our transgenic lines is restricted to a large proportion of forebrain neurons, as indicated by $\beta$-galactosidase immunostaining in a reporter mouse, we cannot rule out that Cre expression driven by the CaMKII $\alpha$ promoter might occur at some point in a subpopulation of glial cells. If that were the case, the resulting inactivation of HIF-1 in glia would certainly contribute to the reduced expression of HIF-dependent proangiogenic molecules in the ischemic HIF- $1 \alpha^{\Delta / \Delta}$ brain.

Given the multifactorial nature of ischemic brain injury, HIF-regulated gene expression is likely to affect various cellular events at different stages of the infarct maturation process. We speculate that activation of HIF-1 is more relevant in the late phase $(>24 \mathrm{~h})$ of stroke recovery. During this phase, the significant reduction in the expression of several metabolic and proangiogenic modulators (and perhaps other beneficial factors that we did not measure) in the HIF- $1 \alpha^{\Delta / \Delta}$ mice ischemic

measurements of local perfusion from superficial layers of the cortex but not from deeper cortical regions or the striatum. This is an important limitation considering that both the cortex and striatum are affected in our MCAo model, and both regions contribute significantly to the overall progression of the stroke in HIF- $1 \alpha^{\Delta / \Delta}$ mice. A more comprehensive analysis of CBF using a tracer such as ${ }^{14} \mathrm{C}$-iodoantipirydine would be required to determine whether local perfusion is altered in HIF- $1 \alpha^{\Delta / \Delta}$ mice compared with wild-type mice, a potential factor that could help explain the differential progression of the infarction after MCAo. Nevertheless, if we assume that the CBF in both striatum and brain results in a suboptimal adaptive response to oxygen deprivation that exacerbates the progressive degeneration of viable tissue surrounding the infarct core. This might explain in part the delayed appearance of the effects of neuronal HIF- $1 \alpha$ knockdown on infarct progression in HIF-1 $\alpha^{\Delta / \Delta}$ mice subjected to MCAo.

An issue that was not addressed in our study is whether the neuronal HIF- $1 \alpha$-deficient mice displayed an augmented inflammatory response after ischemia that could explain the maturation of larger infarcts. Although microglia and infiltrating leukocytes are considered the main inflammatory cells in the ischemic brain, 


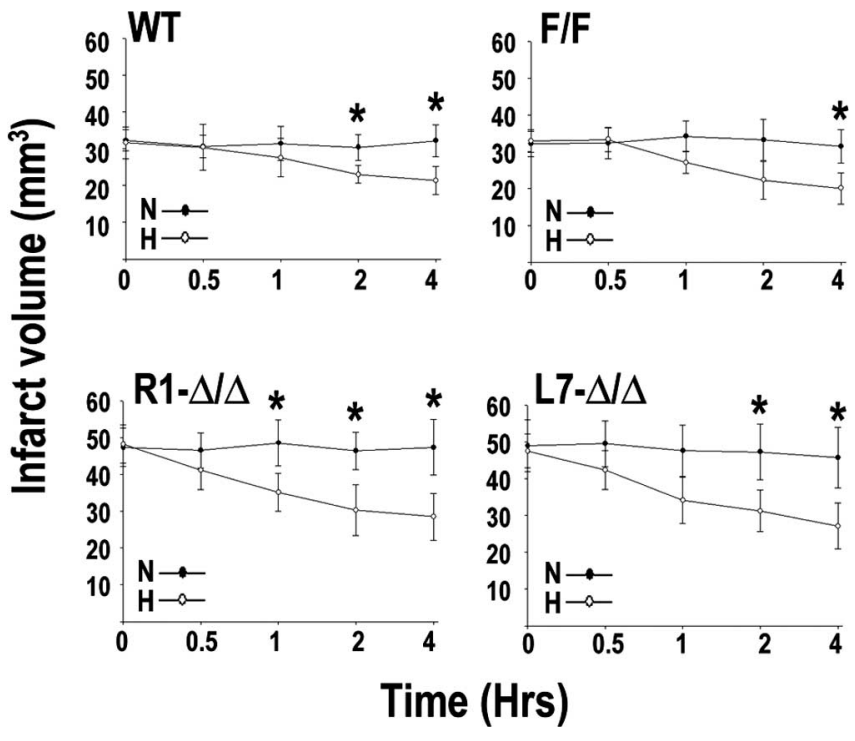

Figure 9. Influence of hypoxic preconditioning on ischemic brain injury. Wild-type C57BL/6 $(\mathrm{Wt}), \mathrm{HIF}-1 \alpha^{\mathrm{F} / \mathrm{F}}$, and R1- and L7-HIF1 $\alpha^{\Delta / \Delta}$ were exposed to normoxia ( $\mathrm{N} ; 21 \% 0_{2}$ ) or hypoxia $\left(\mathrm{H} ; 8 \% \mathrm{O}_{2}\right)$ for the indicated durations, $24 \mathrm{~h}$ before MCAo. Infarct volumes were analyzed at $4 \mathrm{~d}$ of recovery. ${ }^{*} p<0.05$ between hypoxic and normoxic treatments.

ulated by nuclear factor $-\kappa \mathrm{B}(\mathrm{NF}-\kappa \mathrm{B})$ rather than HIF-1, but a potential crosstalk of the HIF- 1 and NF- $\kappa$ B-dependent pathways warrants additional investigation (Kaltschmidt et al., 2002; Nurmi et al., 2004).

Recently, Helton et al. (2005) reported the generation of neuron-specific HIF- $1 \alpha$ knockdown mice using the same HIF$1 \alpha^{\mathrm{F} / \mathrm{F}}$ and R1ag\#5 CaMKII $\alpha-$ Cre transgenic strains used in our study. In this report, HIF- $1 \alpha^{\Delta / \Delta}$ mice subjected to forebrain ischemia induced by bilateral occlusion of the common carotid arteries showed less damage in the hippocampus compared with wild-type mice. This study was the first one to use a genetic approach to study the role of HIF- $1 \alpha$ in cerebral ischemia and provided the first in vivo evidence of a pro-death role of HIF- $1 \alpha$ in the context of an acute global ischemic insult. The authors reported that the upregulation of Vegf and other potentially neuroprotective genes were not altered in the HIF- $1 \alpha^{\Delta / \Delta}$ mice, suggesting a functional redundancy in their regulation. In contrast, in our model of transient focal cerebral ischemia, we found that the post-ischemic expression of Vegf and other HIF-1 target genes was significantly attenuated in the HIF- $1 \alpha^{\Delta / \Delta}$ mice. This discrepancy could be attributed to the severity or duration of the ischemic insult and may explain why, in the context of focal ischemia, the neuroprotective effects of HIF-1 seem to prevail over its pro-death effects. It is important to mention that the stimulation of Epo and Flk-1 expression after MCAo was not affected in the HIF$1 \alpha^{\Delta / \Delta}$ mice. A possible explanation of these findings might be that both genes are not expressed by neurons but by other cells with undisturbed HIF-1 response. We should also consider that the transcriptional control of these genes appear to be HIF-2 rather than HIF-1 dependent. In this regard, it was reported that HIF-2 controls Epo expression in astrocytes and interstitial kidney fibroblasts. Similarly, Flk-1 expression in endothelial cells seems to be regulated by HIF-2 in cooperation with Ets-1.

Several studies have shown that drugs known to inhibit HIF prolyl hydroxylases (PHD1, PHD2, and PHD3) in a nonspecific manner and consequently activate HIF, including iron chelators (DFO and DP) and DHB, have protective properties (Zaman et al., 1999; Bergeron et al., 2000) not only in the brain but also in other tissues such as the heart and kidney. Our results showed that the effectiveness of these compounds in reducing ischemic brain injury was significantly attenuated in HIF$1 \alpha^{\Delta / \Delta}$ mice when given before or after MCAo, suggesting that neuroprotection was achieved mainly through HIF-1 activation. It is also possible that the protective effects of these compounds were obscured by the overwhelming severity of the infarction in the HIF- $1 \alpha^{\Delta / \Delta}$ mice. We think this might not be the case because the differ-

Figure 10. Increased HIF-2 $\alpha$ and Epo expression in HIF- $1 \alpha^{\Delta / \Delta}$ mice. $\boldsymbol{A}$, Western blot analysis of HIF-2 $\alpha$ in brain samples of animals subjected to normoxia (C) $(4 \mathrm{~h})$ or hypoxia $(\mathrm{H})\left(8 \% \mathrm{O}_{2}, 4 \mathrm{~h}\right)$. Protein bands were quantified and normalized to $\alpha$-tubulin, and the value obtained from normoxic wild-type samples $(C, W t)$ was arbitrarily defined as $1 . B, R T-P C R$ and Western blot analysis of Epo in animals subjected to the same experimental conditions as described in $\boldsymbol{A}$. Data are expressed as mean \pm SD from five animals for each genotype including wild-type (Wt), HIF- $1 \alpha^{\mathrm{F} / \mathrm{F}}$, and HIF- $1 \alpha^{\Delta / \Delta} .{ }^{*} p \leq 0.05$ compared with normoxic wild-type (C, Wt). ${ }^{\#} p<0.05$ versus hypoxic wild type $(\mathrm{H}, \mathrm{Wt})$.

previous reports have shown that neurons also express proinflammatory factors such as cyclooxygenase-2 and tumor necrosis factor- $\alpha$ (Nogawa et al., 1997; Sairanen et al., 1998; Ogunshola et al., 2000). Expression of these genes appears to be primarily reg- ences in infarct volumes between wild-type and HIF-1-deficient mice were noticeable only after $48 \mathrm{~h}$ after MCAo. By this time, these drugs, given either before or after treatment, were likely to have already exerted their effects. Another important possibility 
that cannot be ruled out is that DFO, DP, and DHB exert salubrious effects independently of their HIF-activating effects. For instance, their properties as iron chelators could influence other biological processes such as iron-dependent oxidative stress.

Finally, we investigated the role of HIF- $1 \alpha$ in the development of ischemic tolerance after non-injurious hypoxic exposure. Although there are several mechanisms underlying hypoxic preconditioning, the ones that are manifested hours or even days after the hypoxic stimulus are likely to depend on changes in gene expression and de novo protein synthesis (Bernaudin et al., 2002b). In this context, HIF-1-mediated responses, particularly those involved in glucose metabolism and angiogenesis, were postulated to play a key role in mediating hypoxic preconditioning. Surprisingly, neuron-specific knockdown of HIF- $1 \alpha$ did not affect the development of ischemic tolerance in response to hypoxic preconditioning; both wild-type and HIF- $1 \alpha^{\Delta / \Delta}$ mice showed smaller infarcts after preconditioning. Thus, HIF-1 activation in CaMKII $\alpha$-positive neurons does not contribute significantly to hypoxia-mediated tolerance to ischemia. Importantly, our study cannot rule out the possibility that ischemic tolerance involves HIF-1 activation in cell populations in which the CaMKIIa promoter is inactive such as interneurons or glia. Interestingly, in the HIF- $1 \alpha^{\Delta / \Delta}$ mice, we detected significantly higher basal levels of HIF- $2 \alpha$ and Epo and an enhanced upregulation of HIF- $2 \alpha$ and Epo expression in response to hypoxia. This observation suggests that upregulation of HIF- $2 \alpha$ might be a compensatory response to HIF- $1 \alpha$ deletion and may also participate in hypoxia-induced ischemic tolerance in the brain.

In conclusion, the results of our study provide evidence that activation of HIF-1 is part of a homeostatic response aimed at coping with the deleterious effects of ischemic injury. In addition, our study suggests that the neuroprotective effects of pharmacologic HIF prolyl hydroxylase inhibitors in the MCAo model are significantly dependent on HIF-1 activity and further supports the potential of HIF-1 as a target for therapeutic intervention against stroke.

\section{References}

Althaus J, Bernaudin M, Petit E, Toutain J, Touzani O, Rami A (2006) Expression of the gene encoding the pro-apoptotic BNIP3 protein and stimulation of hypoxia-inducible factor-1alpha (HIF-1alpha) protein following focal cerebral ischemia in rats. Neurochem Int 48:687-695.

Bederson JB, Pitts LH, Tsuji M, Nishimura MC, Davis RL, Bartkowski H (1986) Rat middle cerebral artery occlusion: evaluation of the model and development of a neurological examination. Stroke 17:472-476.

Bergeron M, Yu AY, Solway KE, Semenza GL, Sharp FR (1999) Induction of hypoxia-inducible factor-1 (HIF-1) and its target genes following focal ischaemia in rat brain. Eur J Neurosci 11:4159-4170.

Bergeron M, Gidday JM, Yu AY, Semenza GL, Ferriero DM, Sharp FR (2000) Role of hypoxia-inducible factor-1 in hypoxia-induced ischemic tolerance in neonatal rat brain. Ann Neurol 48:285-296.

Bernaudin M, Nedelec AS, Divoux D, MacKenzie ET, Petit E, SchumannBard P (2002a) Normobaric hypoxia induces tolerance to focal permanent cerebral ischemia in association with an increased expression of hypoxia-inducible factor-1 and its target genes, erythropoietin and VEGF, in the adult mouse brain. J Cereb Blood Flow Metab 22:393-403.

Bernaudin M, Tang Y, Reilly M, Petit E, Sharp FR (2002b) Brain genomic response following hypoxia and re-oxygenation in the neonatal rat. Identification of genes that might contribute to hypoxia-induced ischemic tolerance. J Biol Chem 277:39728-39738.

Bruick RK (2000) Expression of the gene encoding the proapoptotic Nip3 protein is induced by hypoxia. Proc Natl Acad Sci USA 97:9082-9087.

Bruick RK (2003) Oxygen sensing in the hypoxic response pathway: regulation of the hypoxia-inducible transcription factor. Genes Dev 17:2614-2623.

Bruick RK, McKnight SL (2001) A conserved family of prolyl-4hydroxylases that modify HIF. Science 294:1337-1340.
Bruick RK, McKnight SL (2002) Transcription. Oxygen sensing gets a second wind. Science 295:807-808.

Chavez JC, LaManna JC (2002) Activation of hypoxia-inducible factor-1 in the rat cerebral cortex after transient global ischemia: potential role of insulin-like growth factor-1. J Neurosci 22:8922-8931.

Chavez JC, Agani F, Pichiule P, LaManna JC (2000) Expression of hypoxiainducible factor-1alpha in the brain of rats during chronic hypoxia. J Appl Physiol 89:1937-1942.

Chavez JC, Baranova O, Lin J, Pichiule P (2006) The transcriptional activator hypoxia inducible factor 2 (HIF-2/EPAS-1) regulates the oxygendependent expression of erythropoietin in cortical astrocytes. J Neurosci 26:9471-9481.

Demougeot C, Van Hoecke M, Bertrand N, Prigent-Tessier A, Mossiat C, Beley A, Marie C (2004) Cytoprotective efficacy and mechanisms of the liposoluble iron chelator 2,2' -dipyridyl in the rat photothrombotic ischemic stroke model. J Pharmacol Exp Ther 311:1080-1087.

Dirnagl U, Iadecola C, Moskowitz MA (1999) Pathobiology of ischaemic stroke: an integrated view. Trends Neurosci 22:391-397.

Dragatsis I, Zeitlin S (2000) CaMKIIalpha-Cre transgene expression and recombination patterns in the mouse brain. Genesis 26:133-135.

Elvert G, Kappel A, Heidenreich R, Englmeier U, Lanz S, Acker T, Rauter M, Plate K, Sieweke M, Breier G, Flamme I (2003) Cooperative interaction of hypoxia-inducible factor-2alpha (HIF-2alpha) and Ets-1 in the transcriptional activation of vascular endothelial growth factor receptor-2 (Flk-1). J Biol Chem 278:7520-7530.

Franklin K, Paxinos G (2000) The mouse brain in stereotaxic coordinates. San Diego: Academic.

Freret T, Valable S, Chazalviel L, Saulnier R, MacKenzie ET, Petit E, Bernaudin M, Boulouard M, Schumann-Bard P (2006) Delayed administration of deferoxamine reduces brain damage and promotes functional recovery after transient focal cerebral ischemia in the rat. Eur J Neurosci 23:1757-1765.

Gidday JM (2006) Cerebral preconditioning and ischaemic tolerance. Nat Rev Neurosci 7:437-448.

Hayashi T, Abe K, Suzuki H, Itoyama Y (1997) Rapid induction of vascular endothelial growth factor gene expression after transient middle cerebral artery occlusion in rats. Stroke 28:2039-2044.

Helton R, Cui J, Scheel JR, Ellison JA, Ames C, Gibson C, Blouw B, Ouyang L, Dragatsis I, Zeitlin S, Johnson RS, Lipton SA, Barlow C (2005) Brainspecific knock-out of hypoxia-inducible factor- $1 \alpha$ reduces rather than increases hypoxic-ischemic damage. J Neurosci 25:4099-4107.

Huang LE, Gu J, Schau M, Bunn HF (1998) Regulation of hypoxiainducible factor lalpha is mediated by an O2-dependent degradation domain via the ubiquitin-proteasome pathway. Proc Natl Acad Sci USA 95:7987-7992.

Ivan M, Kondo K, Yang H, Kim W, Valiando J, Ohh M, Salic A, Asara JM, Lane WS, Kaelin Jr WG (2001) HIFalpha targeted for VHL-mediated destruction by proline hydroxylation: implications for $\mathrm{O} 2$ sensing. Science 292:464-468.

Iyer NV, Kotch LE, Agani F, Leung SW, Laughner E, Wenger RH, Gassmann M, Gearhart JD, Lawler AM, Yu AY, Semenza GL (1998) Cellular and developmental control of $\mathrm{O} 2$ homeostasis by hypoxia-inducible factor 1 alpha. Genes Dev 12:149-162.

Jaakkola P, Mole DR, Tian YM, Wilson MI, Gielbert J, Gaskell SJ, Kriegsheim A, Hebestreit HF, Mukherji M, Schofield CJ, Maxwell PH, Pugh CW, Ratcliffe PJ (2001) Targeting of HIF-alpha to the von Hippel-Lindau ubiquitylation complex by O2-regulated prolyl hydroxylation. Science 292:468-472.

Jin KL, Mao XO, Nagayama T, Goldsmith PC, Greenberg DA (2000) Induction of vascular endothelial growth factor and hypoxia-inducible factor1alpha by global ischemia in rat brain. Neuroscience 99:577-585.

Kaltschmidt B, Linker RA, Deng J, Kaltschmidt C (2002) Cyclooxygenase-2 is a neuronal target gene of NF-kappaB. BMC Mol Biol 3:16.

Lin TN, Wang CK, Cheung WM, Hsu CY (2000) Induction of angiopoietin and Tie receptor mRNA expression after cerebral ischemia-reperfusion. J Cereb Blood Flow Metab 20:387-395.

Lin TN, Nian GM, Chen SF, Cheung WM, Chang C, Lin WC, Hsu CY (2001) Induction of Tie-1 and Tie-2 receptor protein expression after cerebral ischemia-reperfusion. J Cereb Blood Flow Metab 21:690-701.

Marti HJ, Bernaudin M, Bellail A, Schoch H, Euler M, Petit E, Risau W (2000) Hypoxia-induced vascular endothelial growth factor expression 
precedes neovascularization after cerebral ischemia. Am J Pathol 156:965-976.

Nogawa S, Zhang F, Ross ME, Iadecola C (1997) Cyclo-oxygenase-2 gene expression in neurons contributes to ischemic brain damage. J Neurosci 17:2746-2755.

Nurmi A, Lindsberg PJ, Koistinaho M, Zhang W, Juettler E, KarjalainenLindsberg ML, Weih F, Frank N, Schwaninger M, Koistinaho J (2004) Nuclear factor-kappaB contributes to infarction after permanent focal ischemia. Stroke 35:987-991.

Ogunshola OO, Stewart WB, Mihalcik V, Solli T, Madri JA, Ment LR (2000) Neuronal VEGF expression correlates with angiogenesis in postnatal developing rat brain. Brain Res Dev Brain Res 119:139-153.

Pichiule P, LaManna JC (2002) Angiopoietin-2 and rat brain capillary remodeling during adaptation and deadaptation to prolonged mild hypoxia. J Appl Physiol 93:1131-1139.

Ran R, Xu H, Lu A, Bernaudin M, Sharp FR (2005) Hypoxia preconditioning in the brain. Dev Neurosci 27:87-92.

Ryan HE, Poloni M, McNulty W, Elson D, Gassmann M, Arbeit JM, Johnson RS (2000) Hypoxia-inducible factor-1alpha is a positive factor in solid tumor growth. Cancer Res 60:4010-4015.

Sairanen T, Ristimaki A, Karjalainen-Lindsberg ML, Paetau A, Kaste M, Lindsberg PJ (1998) Cyclooxygenase-2 is induced globally in infarcted human brain. Ann Neurol 43:738-747.

Sairanen T, Carpen O, Karjalainen-Lindsberg ML, Paetau A, Turpeinen U, Kaste M, Lindsberg PJ (2001) Evolution of cerebral tumor necrosis factor-alpha production during human ischemic stroke. Stroke 32:1750-1758.

Salceda S, Caro J (1997) Hypoxia-inducible factor lalpha (HIF-1alpha) protein is rapidly degraded by the ubiquitin-proteasome system under normoxic conditions. Its stabilization by hypoxia depends on redoxinduced changes. J Biol Chem 272:22642-22647.

Semenza GL (2000) Surviving ischemia: adaptive responses mediated by hypoxia-inducible factor 1. J Clin Invest 106:809-812.

Semenza GL, Agani F, Booth G, Forsythe J, Iyer N, Jiang BH, Leung S, Roe R, Wiener C, Yu A (1997) Structural and functional analysis of hypoxiainducible factor 1. Kidney Int 51:553-555.

Sharp FR, Bernaudin M (2004) HIF1 and oxygen sensing in the brain. Nat Rev Neurosci 5:437-448.

Sharp FR, Lu A, Tang Y, Millhorn DE (2000) Multiple molecular penumbras after focal cerebral ischemia. J Cereb Blood Flow Metab 20:1011-1032.

Sharp FR, Bergeron M, Bernaudin M (2001) Hypoxia-inducible factor in brain. Adv Exp Med Biol 502:273-291.
Sharp FR, Ran R, Lu A, Tang Y, Strauss KI, Glass T, Ardizzone T, Bernaudin M (2004) Hypoxic preconditioning protects against ischemic brain injury. NeuroRx 1:26-35.

Siddiq A, Ayoub IA, Chavez JC, Aminova L, Shah S, LaManna JC, Patton SM, Connor JR, Cherny RA, Volitakis I, Bush AI, Langsetmo I, Seeley T, Gunzler V, Ratan RR (2005) Hypoxia-inducible factor prolyl 4-hydroxylase inhibition. A target for neuroprotection in the central nervous system. J Biol Chem 280:41732-41743.

Soriano P (1999) Generalized lacZ expression with the ROSA26 Cre reporter strain. Nat Genet 21:70-71.

Van Hoecke M, Prigent-Tessier A, Bertrand N, Prevotat L, Marie C, Beley A (2005) Apoptotic cell death progression after photothrombotic focal cerebral ischaemia: effects of the lipophilic iron chelator 2,2' -dipyridyl. Eur J Neurosci 22:1045-1056.

Wang GL, Semenza GL (1993) Characterization of hypoxia-inducible factor 1 and regulation of DNA binding activity by hypoxia. J Biol Chem 268:21513-21518.

Wang GL, Semenza GL (1995) Purification and characterization of hypoxia-inducible factor 1. J Biol Chem 270:1230-1237.

Wang GL, Jiang BH, Rue EA, Semenza GL (1995) Hypoxia-inducible factor 1 is a basic-helix-loop-helix-PAS heterodimer regulated by cellular $\mathrm{O} 2$ tension. Proc Natl Acad Sci USA 92:5510-5514.

Warnecke C, Griethe W, Weidemann A, Jurgensen JS, Willam C, Bachmann S, Ivashchenko Y, Wagner I, Frei U, Wiesener M, Eckardt KU (2003) Activation of the hypoxia-inducible factor-pathway and stimulation of angiogenesis by application of prolyl hydroxylase inhibitors. FASEB J 17:1186-1188.

Warnecke C, Zaborowska Z, Kurreck J, Erdmann VA, Frei U, Wiesener M, Eckardt KU (2004) Differentiating the functional role of hypoxiainducible factor (HIF)-1alpha and HIF-2alpha (EPAS-1) by the use of RNA interference: erythropoietin is a HIF-2alpha target gene in Hep3B and Kelly cells. FASEB J 18:1462-1464.

Wiesener MS, Jurgensen JS, Rosenberger C, Scholze CK, Horstrup JH, Warnecke C, Mandriota S, Bechmann I, Frei UA, Pugh CW, Ratcliffe PJ, Bachmann S, Maxwell PH, Eckardt KU (2003) Widespread hypoxiainducible expression of HIF-2alpha in distinct cell populations of different organs. FASEB J 17:271-273.

Zaman K, Ryu H, Hall D, O’Donovan K, Lin KI, Miller MP, Marquis JC, Baraban JM, Semenza GL, Ratan RR (1999) Protection from oxidative stress-induced apoptosis in cortical neuronal cultures by iron chelators is associated with enhanced DNA binding of hypoxia-inducible factor-1 and ATF-1/CREB and increased expression of glycolytic enzymes, p21 $1^{\text {waf1/cip1 }}$, and erythropoietin. J Neurosci 19:9821-9830. 